\title{
Effects of intraday weather changes on asset returns and volatilities ${ }^{* 1}$
}

\author{
Hyein Shim ${ }^{2}$, Maria H. Kim ${ }^{3}$, Doojin Ryu
}

\begin{abstract}
Analyzing the intraday dataset on weather and market information with the use of the extended GJR-GARCH framework, this study explores in depth the weather effects on the asset returns and volatilities of the Korean stock and derivatives markets. Our intraday analyses contribute to the existing literature by going beyond the attempt of prior studies to capture the weather effects using the average daily observations alone. The empirical results document a modest presence of the weather effect on the returns and volatilities, though the significance of its impact is found to vary across different market conditions and indices. We also find that the return and volatility respond asymmetrically to extremely good and bad weather conditions. The intraday analyses show that the weather effect on the returns and volatilities is more statistically significant at the beginning of the working day or the lunch break, indicating the intraday weather effects on the financial market.
\end{abstract}

Key words: asset returns, behavioral finance, GJR-GARCH, intraday analyses, weather effect, volatility

JEL classification: G02, G14, G15

* Received: 16-05-2017; accepted: 21-12-2017

1 This work was supported by the Ministry of Education of the Republic of Korea and the National Research Foundation of Korea [NRF-2017S1A5A2A01025583].

2 PhD in Economics, Research Fellow of Korea Public Finance Information Service, Metrotower, 10, Toegye-ro, Jung-gu, Seoul, 04637, Republic of Korea. Scientific affiliation: macroeconomics, public finance, econometrics. Phone: +82 26908 8568. Fax: +82 26312 8959.E-mail: hyein@ kpfis.kr.

3 PhD Lecturer of Finance, University of Wollongong, Northfields Avenue, Wollongong, New South Wales 2522, Australia. Scientific affiliation: bankruptcy prediction modelling, credit rating risk modelling, corporate governance, earnings management. Phone: +61 242214759 . Fax:+61242214297.E-mail:mhykim@uow.edu.au.

4 Tenured Professor of Sungkyunkwan University, College of Economics, 25-2, Sungkyunkwan-ro, Jongno-gu, Seoul 03063, Republic of Korea. Scientific affiliation: asset pricing, financial economics, marketmicrostructure.Phone:+82 2760 0429.Fax:+8227600950.E-mail: sharpjin@skku.edu. Personal website: https://sites.google.com/site/doojinryu/home/info (corresponding author). 


\section{Introduction}

Previous studies in the field of behavioral finance examine the association between investor sentiments and stock market returns (Baker and Wurgler, 2006; Baker et al., 2012; Kim et al., 2014; Ryu et al., 2017; Yang et al., 2017b). They find that individuals tend to make trading decisions based on noise rather than information (Black, 1986; Kahneman and Riepe, 1998), which is contrary to the assumption of the rational asset pricing framework and the efficient markets hypothesis (Fama, 1970; Kyle, 1985). They also find that, unlike the Bayesian or other probability theories, investor sentiment can forecast uncertain future outcomes (Kahneman and Tversky, 1973).

The psychology literature shows that investor moods and emotions significantly affect their memory, judgment, and evaluation processes. That is, economic agents tend to make positive judgments or evaluations when they are in a good mood, in an effort to maintain their induced moods (Bagozzi et al., 1999; Isen et al., 1978; Johnson and Tversky, 1983; Mayer and Hanson, 1995; Nasby and Yando, 1982; Schwarz and Clore, 1983; Wright and Bower, 1992). Empirical evidence suggests that decision making, in particular, is significantly influenced by individuals' sentiments when they are exposed to risky or uncertain situations (Loewenstein et al., 2001). Therefore, it is plausible to conjecture that individuals' sentiments would have a substantial impact on their investment decisions in the financial capital market, which is characterized by high levels of complexity and volatility.

The literature on behavioral finance applies the concepts relating to the psychological process of emotions to financial capital market dynamics. It commonly uses weather-related variables as psychosocial proxies, since the weather effect is recognized as being associated with well-known market anomalies. Unlike other anomalies that have rational and behavioral explanations, weather conditions only refer to the psychological grounds that are involved in stock market decision making (Hirshleifer and Shumway, 2003). In addition, weather-related variables are readily measured exogenous factors. Since the 1990s, behavioral finance studies have been debating extensively: whether or not weather conditions can exert an exogenous economic influence, and whether or not psychological biases caused by the weather can affect financial asset prices. Saunders (1993) analyzes the correlation between the weather conditions of New York City and daily return changes in the NYSE/AMEX index, and finds that weather conditions have a significant impact on the changes in stock prices when used as proxies for investor sentiments. Following the seminal work of Saunders (1993), many studies, including those by Cao and Wei (2005), Hirshleifer and Shumway (2003), and Kamstra et al. (2003), support Saunders's (1993) view, while others find little evidence of the weather effect on stock returns suggested by Saunders (Krämer and Runde, 1997; Trombley, 1997). More recently, researchers have been investigating 
the patterns of trading volume, volatility, and stock returns to analyze the weather effect on overall stock market activities. More diverse approaches, including the use of intraday data, are being used for such analyses.

This study explores in depth the evolution of the research examining the effect of weather on the stock market. This study is motivated by the need to meet the following three objectives. First, we employ intraday weather and stock market data to test our conjecture that the magnitude of the weather effect would vary at different times of the day. Pizzutilo and Roncone (2016) argue that most of the extant literature overlooks the fact that investor moods can be affected by many other factors during the day and that the stock market is continually exposed to the arrival of new information. They go on to observe that analyzing the effect of the weather on a daily basis (i.e., using the average value of daily observations) can lead to biased results. For instance, people have more exposure to the external climate conditions at the beginning of a working day, or in the short period after they enter their workplace, rather than during the middle of the working day. Thus, if the weather effect on asset prices indeed exists, its impact should be most evident at the beginning of the working day. Nevertheless, only a few studies, including those by Chang et al. (2008), Lu and Chou (2012), and Pizzutilo and Roncone (2016), use intraday data for weather effect analyses.

Second, we document the volatility behavior as well as the stock returns in response to the weather effect. A number of studies including those by Baker and Stein (2004), Brown (1999), and Wright and Bower (1992) point out that weather conditions can change the risk preference of investors, valuation of financial assets, and trading willingness; thus, they have a significant influence on market volatility. Chang et al. (2008), Lu and Chou (2012), and Symeonidis et al. (2010) provide empirical evidence to support the argument that the weather effect can be better captured by volatility than stock returns. However, relatively few extant studies pay attention to the volatility behavior. An empirical result about this aspect, which is attempted in this study can add to the existing literature on the weather effect on the stock markets.

Finally, location is one of the most critical factors in weather effect analyses, since climate conditions vary with place. Moreover, some degree of variation would exist with regard to individuals' characteristics and their psychological traits across regions and cultures; thus, it is likely that varied market reactions can be elicited in response to the same weather conditions, based on the stock exchange location. Some existing studies emphasize the heterogeneous effects of weather conditions on various stock markets. For example, Keef and Roush (2007a) assert that the significance of the cloud cover effect on stock returns varies by the geographical location of the stock exchange. Considering this, we investigate the weather effect on the Korean financial market, a leading emerging market. These empirical results would provide significant implications, given the market's economic scale among 
the emerging markets and its unique institutional setting (Lee et al., 2016). In particular, we also analyze the VKOSPI, which is the model-free implied volatility index of the Korean market, derived from the KOSPI200 options price dynamics. Considering that the KOSPI200 options market records quite large trading volumes, compared with other leading derivatives markets, it is more prudent to examine the volatility index. ${ }^{5}$ Interestingly, unlike other stock markets in developed countries, where institutional investors are major market players, the Korean market is characterized by a very high participation rate of domestic individual investors (Ahn et al., 2008; Ryu et al., 2017a). Considering that the individual investors are noisy and are easily affected by the prevailing mood and sentiment (Sim et al., 2016; Yang et al., 2017a), the intraday Korean market dataset provides an ideal setting to analyze the weather effects.

Based on these motivations and arguments, the main research hypotheses is that the weather changes affect both asset returns and volatility dynamics of the Korean market via the changes in investor mood and sentiment. In addition, we argue that the magnitude of the weather effect varies with the progress of the trading day and, also, asset return and volatility dynamics can asymmetrically change in response to extremely high and low values of weather conditions.

Our empirical results show that unexpected weather conditions have a modest impact on the KOSPI200 returns and the historical volatility of KOSPI200 futures, though the degree of influence is inconsistently observed across market indices. We also find that the spot and futures returns are more sensitive to extremely low weather conditions than to extremely high weather conditions. While both extremely high temperature and humidity increase the volatility, extremely low temperature and humidity result in an increase and decrease, respectively, of volatility. The hourly analysis reveals that the weather effect on the returns and volatilities is more statistically significant right after the beginning of the working day or during the lunch break interval, when people are more exposed to the external environment. In addition, we find differing estimation results with regard to the coefficients of the significant variables when we use hourly observations instead of daily observations; this indicates the presence of an hourly weather effect on the stock market.

The remainder of this study consists of five interconnected parts. Section 2 introduces related literatures in the field of behavioral economics and finance. Section 3 describes the sample data and methodology used for the analyses. Section 4 explains the sample dataset constructed for this study and presents the empirical results. Section 5 elaborates on the economic significance of results, their relation

\footnotetext{
5 The previous literature explains the traits and characteristics of the KOSPI200 options market. Refer to Chung et al. (2016) and Ryu (2011).
} 
to previous research and interpretations, and provides the interpretations and implications. Section 6 concludes this study.

\section{Literature review}

Several studies on behavioral economics and finance test the effects of weather conditions on the stock market, given that these conditions affect the mood of investors. They find a significant causal effect of psychological biases on stock returns. Saunders's (1993) seminal work examines the relationship between weather conditions and investors' decision making. He reports a negative relationship between cloudy weather and the daily index returns of exchanges in New York City. Using the daily climatological data (including that on cloud cover) for New York City as a proxy for the mood variables, and the changes in daily return of the NYSE/AMEX index, Saunders (1993) shows that investor psychology has a significant correlation with changes in asset prices, and documents a positive sunshine effect on investors' behavior in the stock market. His results also show that the positive sunlight effect on stock returns is robust to other market anomalies related to the month (January), weekend, and small-firm effects.

Hirshleifer and Shumway (2003) extend the work of Saunders (1993) to conduct a systematic analysis on the correlation between the measures of cloud cover for 26 of the world's major cities and the daily returns of the corresponding stock market index, which includes emerging stock markets. They document a statistically significant negative relationship between cloudiness and stock index returns, and these results are neither market- or city-specific. A substantial sunlight effect on stock returns is evidenced in most of the sample cities under investigation, except those in Australia and countries with high humidity (e.g., Southeast Asian countries), and this effect is found to be more pronounced in north European countries having little exposure to sunshine. Their result suggests that trading strategies allowing for weather effects on returns would moderately improve the Sharpe ratio of the market portfolio, given relatively low transaction costs. Kamstra et al. (2003) analyze the seasonal cycle of stock returns according to the seasonal variation in daylight time and find a strong correlation between fewer hours of daylight and lower stock returns. Their results are substantial and significant for stock market index data from nine countries that are geographically dispersed and at various latitudes in both hemispheres. In general, the higher the latitude, the stronger the effect of daylight on stock returns. Meanwhile, Cao and Wei (2005) examine the correlation between temperature and stock returns based on the stock market indices of the US, Australia, Britain, Canada, Germany, Sweden, Japan, and Taiwan. They find that lower (higher) temperature is associated with higher (lower) returns. The observed negative correlation is statistically significant and remains strong even after controlling 
for various market anomalies. Furthermore, statistically significant correlations between weather variables and stock market returns are documented in the prior literature. For example, the significant influence of wind (Wellington's weather) on the returns of stocks listed on the New Zealand Stock Exchange (Keef and Roush, 2002); a significant relationship between mood proxy variables (rain) and daily Irish stock returns (Dowling and Lucey, 2005); the significant effects of temperature and cloud cover on Taiwan's stock market returns (Chang et al., 2006); a negative correlation between temperature and the daily returns of Australian stock indices (Keef and Roush, 2007b), a relationship between UK equity markets and climatic conditions, such as temperature and wind speed (Dowling and Lucey, 2008), the existence of the weather effect - as measured by temperature, humidity, and sunshine duration - on the Shanghai A- and B-share indexes (Kang et al., 2010); a negative influence of temperature on the PSI 20 index returns of the Lisbon Stock Exchange (Floros, 2011); and the association between the Israeli Stock Exchange index returns and natural phenomena variables, including wind velocity, temperature, rain, and earthquakes (Nissim et al., 2012).

On the other hand, a number of studies question the validity of the weather effect on stock returns. Krämer and Runde (1997) and Trombley (1997) challenge the findings of Saunders (1993) on the local weather's effect on stock market prices. Trombley (1997) finds little evidence of significant differences between the stock returns on sunny days and the stock returns on rainy days. Krämer and Runde (1997) replicate the approach used by Saunders (1993) with German stock markets data but find no systematic relationship between weather and stock returns. They point out an issue with regard to data mining, namely that the results can be subject to test procedures and methodological variants (e.g., variable definition, data classification, choice of test statistics, etc.). Jacobsen and Marquering (2008) observe strong seasonal patterns in stock returns for many international stock markets; however, they suggest that a simple summer/winter dummy variable explains the seasonality better than the temperature variation or the seasonal affective disorder (SAD) effect. Their findings also indicate that the results related to the correlation between weather variables and stock returns are spurious and tend to be data-driven inferences.

Meanwhile, the recent literature exhibits a more diverse set of empirical approaches. First, besides the stock return measures, analysis on trading volumes and volatilities is being considered. Goetzmann and Zhu (2005) examine the weather effect using the database of individual investors from five major cities in the US over a six-year sample period. They find little difference in the propensity of individual investors to buy or sell securities on cloudy days compared to sunny days, but find a negative association between NYSE daily index returns and cloud cover of New York City at the $1 \%$ significance level. They finally suggest that market makers' behavior, rather 
than that of individual investors, accounts for the relation between the weather and the stock returns. Symeonidis et al. (2010) empirically test the association between the stock volatilities and investors' behavior by using the index returns from 26 international stock exchanges and weather- (cloud cover, temperature, and precipitation) and environment-related (the length of night time) variables as proxies for investors' mood. They find that the historical, implied, and realized return volatilities are inversely related to cloudiness and the length of night time, though the results can vary according to the exchange location. Shim et al. (2015) investigate how historical and implied volatilities have responded to unexpected weather conditions, using the Korean stock market data. They document increased volatilities during cloudy and humid conditions but decreased volatilities on windy days. ${ }^{6}$

Second, the use of intraday data for analysis has been increasing. Using the intraday data on NYSE stocks during the period 1994 to 2004, Chang et al. (2008) observe relatively lower stock returns on cloudier days, but find that the effect of cloud cover on stock prices is significant only for the first 15 minutes after the market opens. They also document a higher number of seller-initiated trades on cloudy days, a result that is significant for the first 15 minutes after the market opening. They suggest that cloud cover is related to high volatilities and low market depth, and that the effect is observed throughout the trading day. Lu and Chou (2012) provide an intraday analysis of trading activities and stock index returns on a pure order-driven market, such as the Shanghai Stock Exchange of China, and find that mood changes in response to weather conditions tend to reduce market turnover and liquidity but have little impact on stock index returns. More recently, Pizzutilo and Roncone (2016) conduct an intraday analysis using a large set of stocks listed on the Italian stock exchange and show there is little evidence to support the systematic relationship between weather-related variables and stock market behavior. They further suggest that weather effect analysis using stock indices tends to be entirely data-driven and leads to spurious results.

\section{Methodology}

To analyze the effect of unexpected weather conditions on stock returns, we select the Glosten, Jagannathan, and Runkle-generalized autoregressive conditional

\footnotetext{
6 Prior studies that examine the weather effects on the Korean financial market include Yoon and Kang (2009) and Shim et al. (2015). Although our study is similar to that of Yoon and Kang (2009) in that both provide a comparative analysis of the weather effects during the pre- and post-crisis periods, our study goes beyond the examination of the effect of stock returns to investigate the effect on volatilities too. Shim et al. (2015) also examine the weather effect on the volatilities. However, they merely use the daily weather data, whereas our study includes hourly weather observations, and thus, provides a finer and more dynamic analysis than can be derived from the use of daily observations.
} 
heteroskedastic (GJR-GARCH) model, to capture asymmetries in the volatility process. ${ }^{7}$ We modify the GJR-GARCH$(1,1)$ process as follows:

$$
\begin{gathered}
\Delta R_{t}=\alpha_{0}+\alpha_{1} \Delta R_{t-1}+\alpha_{2} \Delta R_{t-2}+\sum_{i=1}^{4} \eta_{i} D H_{i t}+\sum_{i=1}^{4} \chi_{i} D L_{i t}+\in_{t} \text {, where } \in_{t \mid} \Omega_{t-1} \sim N\left(0, h_{t}\right), \\
h_{t}=\omega+\theta h_{t-1}+\delta \in_{t-1}^{2}+\gamma \in_{t-1}^{2} I_{\left\{\in_{t-1}<0\right\}} .
\end{gathered}
$$

In the mean equation (Equation 1), $R_{t}\left(=100 \ln \left(P_{t} \mid P_{t-1}\right)\right)$ is the daily nominal percentage return of the KOSPI200 spot price or the KOSPI200 futures price at time $t\left(P_{t}\right) . D H_{i t}$ and $D L_{i t}$ denote the matrices of dummy variables that are proxies for extreme weather conditions. In other words, the dummy variables $D H_{\text {temp }}, D H_{\text {wind }}$, $D H_{\text {hum }}$, and $D H_{s s}\left(D L_{\text {temp }}, D L_{\text {wind }}, D L_{\text {hum }}\right.$, and $\left.D L_{s s}\right)$ denote extremely high (extremely low) weather conditions. $\in_{t}, \Omega_{t}$, and $h_{t}$ refer to the error term, information set, and conditional variance at time $t$, respectively. In the variance equation (Equation 2), $\epsilon_{t}^{2}$ is the residual series from the mean equation and $I$ is an indicator variable, where $I=1$ if $\in_{t-1}<0$, and $I=0$ if $\in_{t-1} \geq 0$.

Following Hirshleifer and Shumway (2003) and Pizzutilo and Roncone (2016), we also employ a logit regression model (Equation 3) in order to estimate the likelihood that unexpected weather factors would lead to positive stock returns.

$$
\operatorname{Pr}\left(R_{t}>0\right)=a_{0}+\sum_{i=1}^{4} \eta_{i} D H_{i t}+\sum_{i=1}^{4} \chi_{i} D L_{i t}+v_{t}
$$

where $\operatorname{Pr}\left(R_{l}>0\right)$ is the probability of positive return. $R_{t}, D H_{i t}$, and $D L_{i t}$ have the same definitions as in Equation (1) and $v_{t}$ denotes the error term at time $t$.

To assess the weather effects on volatility, we conduct the estimation using the ordinary least squares (OLS) regression model, assuming Newey-West heteroskedasticity and autocorrelation consistent (HAC) standard errors and covariance as follows:

$$
V_{t}=a_{0}+a_{1} V_{t-1}+a_{2} V_{t-2}+\sum_{i=1}^{4} \eta_{i} D H_{i t}+\sum_{i=1}^{4} \chi_{i} D L_{i t}+u_{t}
$$

where $V_{t}$ is the VKOSPI or the historical volatility of the KOSPI200 futures at time $t$, and $D H_{i t}$ and $D L_{i t}$ are the weather variable matrices, as mentioned above. $u_{t}$ denotes the error term.

\footnotetext{
7 Among the GARCH-family models, the GRJ-GARCH model is the most widely used model that captures the asymmetric volatility phenomenon. We also test other GARCH-family models, such as GARCH and EGARCH models, to strengthen the robustness of the results obtained. The results of all the tests carried out do not change our overall conclusion. Furthermore, we find that the GJRGARCH model exhibits the best model-fitness and can be easily extended to accommodate all our research variables. For the sake of brevity, we only discuss the estimation results of the GJR-GARCH model in this paper.
} 


\section{Empirical data and analysis}

\subsection{The Korean financial market}

As shown in Section 2, researchers in this area are employing various approaches; yet, the validity of the weather effect on market activities and asset price dynamics is still in doubt. We employ the intraday weather and financial market data to provide a more detailed and in-depth analysis, which cannot be obtained from the use of daily average observations. This study provides empirical evidence of the weather effect on the Korean stock and derivatives market, which is a leading emerging market and is among the top-tier financial markets of the world. The Korean market provides an ideal setting to investigate the causal associations among the weather condition, psychological behavior of investors, and financial market dynamics. It is worth examining the return and volatility behavior in response to changes in weather conditions, given the market's uniquely high rate of individual investor participation.

According to the statistics provided by the Korea Exchange (KRX), the trading volumes of financial securities in the Korean stock market increased to 113 billion (as of 2015) from 93 billion recorded in 2004, with domestic individual trades accounting for $89 \%$ of all trades in 2004 and $86 \%$ in 2015 . The KOSPI 200 futures market, one of the highly liquid index derivatives markets, also has a substantial participation of individual investors; trades by domestic individual investor were $48 \%$ of all trades in 2004 and $27 \%$ in 2015 . Although there is decreased decline in the percentage share of domestic investors, they still account for a significant proportion of the total trading. The predominant participation of individual investors in the Korean financial market provides an ideal setting to examine empirical evidence of the psychological impact on investment-related decision making attributed to changes in weather conditions.

\subsection{Sample data construction}

We employ four hourly weather variables-temperature (TEMP), wind speed (WIND), humidity (HUM), and sunshine duration (SS) - for South Korea's capital, Seoul. ${ }^{8}$ TEMP is the average temperature per hour, expressed in degrees Celsius, and WIND is the speed of the wind measured in meters per second $(\mathrm{m} / \mathrm{s}) . H U M$

\footnotetext{
$\overline{8}$ The geographical setting of South Korea makes it susceptible to typhoons during the summer and autumn seasons. This may give rise to the reasonable assumption that the Korean stock market can be susceptible to the effect of typhoons. Nevertheless, one of the major reasons for the exclusion of the typhoon-related variables is that the data on typhoons are either absent or incomplete. The typhoonrelated data in South Korea are available only for the limited period of its occurrence and dissipation, and data about the duration of typhoons in Seoul are not obtainable. Therefore, we used extremely high wind speed as a proxy for the effects of typhoon conditions; however, the regression result does
} 
denotes the relative humidity, which is expressed as a percentage. SS is the duration of sunshine, expressed in minutes per hour, and ranges from 0 to 1 . We obtain the data from the National Climate Data Service System (http://sts.kma.go.kr). Given the possibility of the seasonality in data influencing the weather effect calculations, the raw weather data is processed in the following manner. First, for each weather variable (TEMP, WIND, HUM, and SS), a given average (mean value of the prior 24-hour observation) is subtracted from the value of each observation and the squared value is computed. The computed value indicates the magnitude of deviation, and provides a deseasonalized value of the weather variable in question. Second, two types of dummy variables $(D H$ and $D L$ ) that proxy for extreme weather conditions for each weather variable are constructed. The dummy variables $D H_{\text {temp }}, D H_{\text {wind }}, D H_{\text {hum }}$, and $D H_{s s}\left(D L_{\text {temp }}, D L_{\text {wind }}, D L_{\text {hum }}\right.$, and $\left.D L_{s s}\right)$ denote extremely high (extremely low) weather conditions, and are set to one if the deseasonalized value belongs to the top quintile (the lowest quintile), and zero otherwise.

To examine the market response to the weather conditions, we use the KOSPI200 spot index and the VKOSPI derived from the KOSPI200 option prices. ${ }^{9}$ Moreover, we consider the KOSPI200 futures price and its historical volatility as dependent variables in order to provide a comparative analysis of the weather effect on the dynamics of the futures market, which is known to be not only sensitive to investor sentiment, but also have a relatively high rate of individual investor participation. The hourly observations of historical volatility are constructed using the KOSPI200 futures price data recorded at one-minute intervals. For example, in order to obtain the volatility value at 11:00, the maximum value $(H)$ and the minimum value $(L)$ are extracted from a total of 60 observations from 10:00 to 10:59, and the value at $11: 00$ am is computed as $(H-L) / M$, where $M=(H+L) / 2 .{ }^{10}$

The entire sample period of our data ranges from January 4, 2000 to October 8, 2014, and is divided into three sub-periods for the analysis. Notably, our sample period (2000-2014) includes the time period of the global financial crisis, when financial markets worldwide underwent severe turmoil. Cornett et al. (2011), Mian and Sufi (2009), Mian et al. (2010), Reinhart and Rogoff (2008), and Rose and Spiegel (2012) report that financial markets have been highly volatile and the correlations between overseas markets became amplified during the 20072008 global financial crisis period. In the wake of the crisis, financial institutions have been pursuing more stable financial market policies and conducting

not provide statistically significant evidence of typhoon effects on the Korean stock market. We are grateful to the anonymous reviewers for their useful suggestion.

9 For the sample period lacking the VKOSPI data (i.e., 2003 to 2008), one can construct the VKOSPI series using the formula provided by the KRX. For details on the VKOSPI and its application, refer to Song et al. (2016) and Park et al. (2017).

${ }^{10}$ Note that the historical volatility of the KOSPI200 index futures price at 9:00 would have a null value as the price data prior to the market's opening are not available. 
Hyein Shim, Maria H. Kim, Doojin Ryu • Effects of intraday weather changes on asset...

revolutionary reforms and restructuring. Thus, we divide our sample period into three sub-periods - pre-crisis, crisis, and post-crisis - in order to examine if such macroeconomic changes induce different weather effects on the stock market.

The sub-periods include the pre-crisis period from 2000 to 2007, the crisis period from 2008 to 2009, and the post-crisis period from 2010 to 2014, given the turmoil unleashed by the global financial crisis on the global stock markets. ${ }^{11}$

Table 1 reports the summary statistics for the returns, volatilities and weather variables used in this study.

Table 1: Descriptive statistics

\begin{tabular}{|l|r|r|r|r|r|r|}
\hline \multicolumn{1}{|c|}{ Variable } & \multicolumn{1}{c|}{ Mean } & Median & Maximum & Minimum & Std. Dev. & Observations \\
\hline RET_k & $0.005 \%$ & $0.01 \%$ & $6.47 \%$ & $-8.11 \%$ & 0.0054 & 16,486 \\
\hline RET_f & $0.003 \%$ & $0.00 \%$ & $8.60 \%$ & $-9.14 \%$ & 0.0066 & 25,528 \\
\hline PrRET_k & 0.517 & 1 & 1 & 0 & 0.4997 & 16,486 \\
\hline PrRET_f & 0.496 & 0 & 1 & 0 & 0.5000 & 25,505 \\
\hline HL_VOL & 0.007 & 0.005 & 0.077 & 0 & 0.4997 & 21,877 \\
\hline VKOSPI & 22.9 & 19.4 & 90.8 & 9.8 & 0.5000 & 11,489 \\
\hline TEMP & 14.6 & 16.2 & 35.7 & -17.9 & 0.0049 & 25,528 \\
\hline WIND & 2.8 & 2.6 & 11.4 & 0.0 & 11.471 & 25,528 \\
\hline HUM & 53.6 & 52.0 & 100.0 & 10.0 & 10.872 & 25,528 \\
\hline $\mathrm{SS}$ & 0.6 & 0.7 & 1.0 & 0.0 & 1.4037 & 25,520 \\
\hline $\mathrm{DH}_{\text {temp }}$ & 0.091 & 0 & 1 & 0 & 19.736 & 25,505 \\
\hline $\mathrm{DH}_{\text {wind }}$ & 0.091 & 0 & 1 & 0 & 0.4405 & 25,505 \\
\hline $\mathrm{DH}_{\text {hum }}$ & 0.092 & 0 & 1 & 0 & 0.2872 & 25,505 \\
\hline $\mathrm{DH}_{\mathrm{ss}}$ & 0.093 & 0 & 1 & 0 & 0.2878 & 25,505 \\
\hline $\mathrm{DL}_{\text {temp }}$ & 0.091 & 0 & 1 & 0 & 0.2892 & 25,505 \\
\hline $\mathrm{DL}_{\text {wind }}$ & 0.091 & 0 & 1 & 0 & 0.2900 & 25,505 \\
\hline $\mathrm{DL}_{\text {hum }}$ & 0.091 & 0 & 1 & 0 & 0.2876 & 25,505 \\
\hline $\mathrm{DL}_{\mathrm{ss}}$ & 0.091 & 0 & 1 & 0 & 0.2874 & 25,505 \\
\hline
\end{tabular}

Note: RET_k, RET $f$, PrRET_k,PrRET $f$, HL_VOL, VKOSPI, TEMP, WIND, HUM, and SS denote the KOSPI200 spot return, KOSPI200 futures return, the probabilities of positive KOSPI200 spot and futures returns, historical volatility of the KOSPI200 futures, VKOSPI, temperature, wind speed, humidity, and sunshine duration, respectively. $D H_{\text {temp }}, D H_{\text {wind }}, D H_{\text {hum }}$, and $D H_{s s}\left(D L_{\text {temp }}, D L_{\text {wind }}, D L_{\text {hum }}\right.$, and $\left.D L_{s s}\right)$ are dummy variables for extremely high (extremely low) temperature, wind speed, humidity, and duration of sunshine, respectively.

Source: Authors' calculations

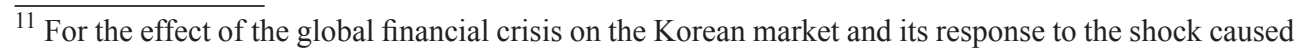
by it, refer to Kim et al. (2015). 
The mean, maximum and minimum values of KOSPI200 spot returns over the whole sample period are $0.005 \%, 6.47 \%$, and $-8.11 \%$, respectively, and those of KOSPI200 futures returns are $0.003 \%, 8.60 \%$, and $-9.14 \%$, respectively. The mean values of the historical volatility of the KOSPI200 futures and VKOSPI are 0.007 and 22.9, respectively. As for the weather variables, the mean values of temperature, wind speed, humidity, and sunshine duration are $14.6^{\circ} \mathrm{C}, 2.8 \mathrm{~m} / \mathrm{s}, 53.6 \%$, and 0.6 $\mathrm{hrs} / \mathrm{hr}$, respectively. The probability measures, PrRET_k and PrRET $f$, have values between zero and one, and the dummy variables of extremely high (extremely low) weather conditions including $D H_{\text {temp }}, D H_{\text {wind }}, D H_{\text {hum }}$, and $D H_{s s}\left(D L_{\text {temp }}, D L_{\text {wind }}\right.$, $D L_{\text {hum }}$, and $D L_{s s}$ ) are assigned a value of either zero or one. Notably, the augmented Dickey-Fuller test rejects the null hypothesis, indicating the absence of a unit root for all the variables used.

\subsection{Effect of Intraday weather changes on stock returns}

Tables 2 and 3 present the regression results of the GJR-GARCH $(1,1)$ model used in Equations (1) and (2) to capture the stock return in the event of unexpected weather conditions. Table 2 reports significant intraday weather effects on the KOSPI200 spot returns. The result for the whole sample period (column 2) shows that the variables of extremely high and low temperature $\left(D H_{\text {temp }}\right.$ and $\left.D L_{\text {temp }}\right)$ estimate positive and statistically significant coefficients. The results of the regressions on the three sub-sample periods show that extremely low temperatures $\left(D L_{\text {temp }}\right)$ have a positive relation with stock returns during and after the crisis period (see the last two columns). Moreover, these findings are statistically significant. For the pre-crisis period (column 3$)$, extremely high humidity $\left(D H_{\text {hum }}\right)$ has a significantly negative impact on the difference in returns.

Table 3 reports the results of the regression on the KOSPI200 futures returns. We find little evidence of intraday weather effect on the futures market returns, except for the positive impact of extremely high temperature $\left(D H_{\text {temp }}\right)$, which is statistically significant only for the post-crisis period. 
Hyein Shim, Maria H. Kim, Doojin Ryu $\bullet$ Effects of intraday weather changes on asset...

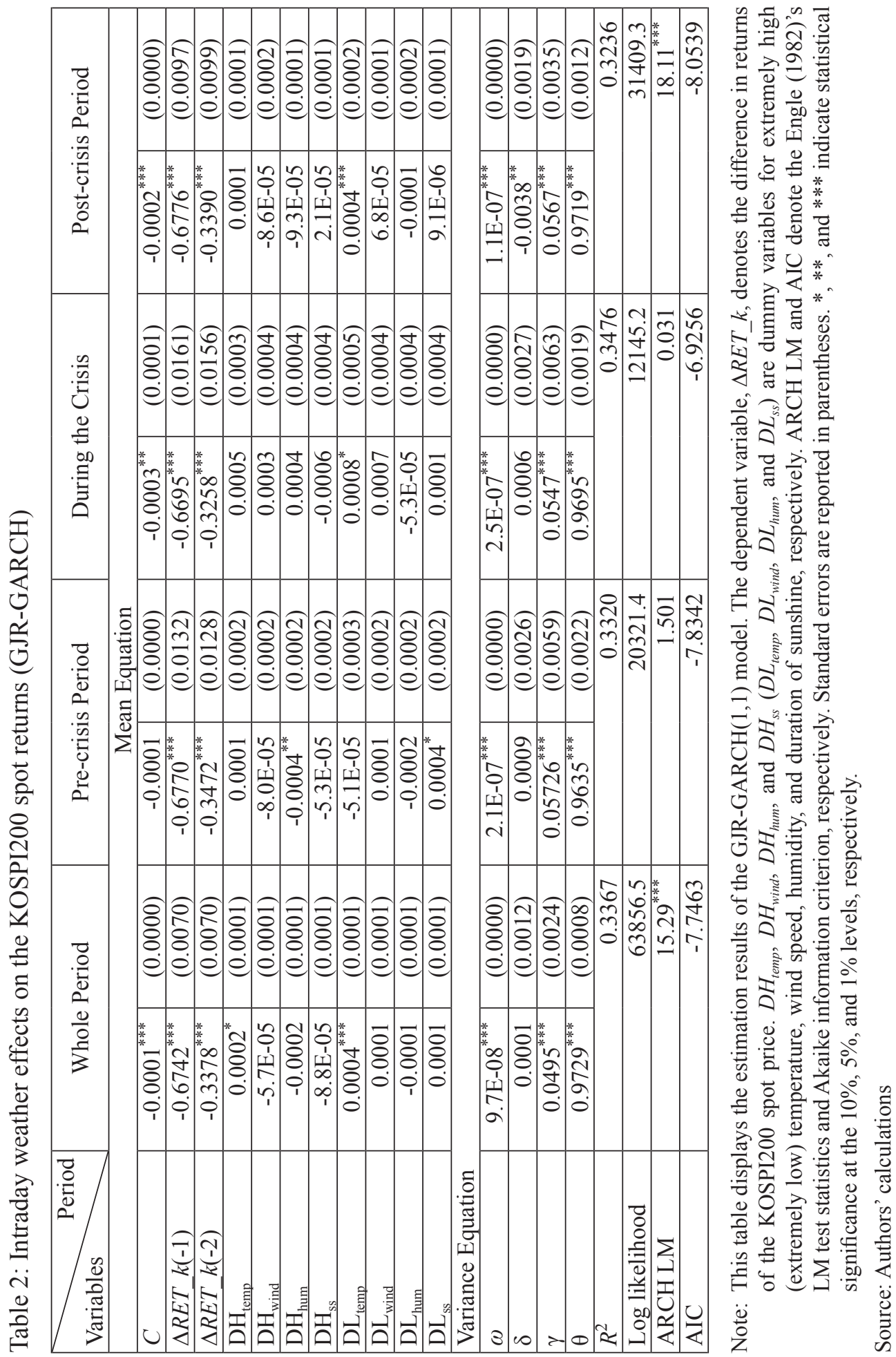


Hyein Shim, Maria H. Kim, Doojin Ryu • Effects of intraday weather changes on asset...

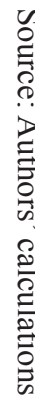

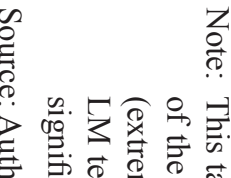

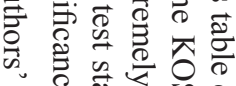

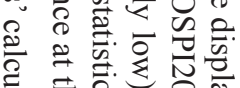

产

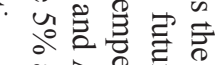

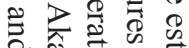

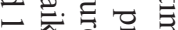

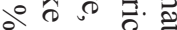

ऽ ङ

㑒它

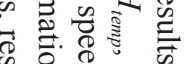

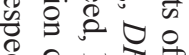

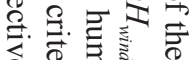

.

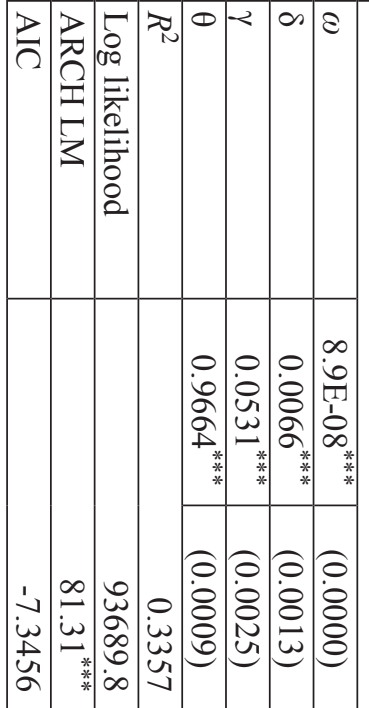

Zb. rad. Ekon. fak. Rij. $2017 \cdot$ vol. $35 \cdot$ no. $2 \cdot 301-330$

旅

要害家

表

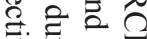

$\checkmark$ II

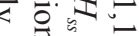

记

है

包

$\vec{\partial} \bar{\rho}$ के के के :

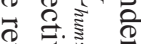

8 年

产艺

$\therefore \rightarrow 2$

E. 品它

त 0

它苍令

当等

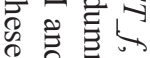

娄 क

$*$ *

औ :

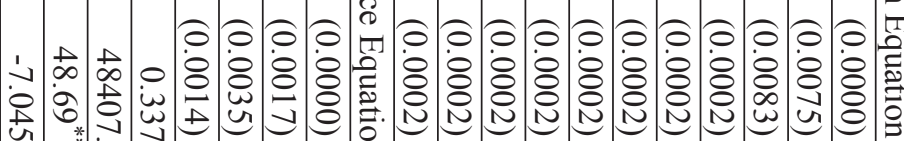

$\because 00$ 인

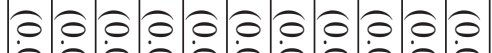

৪

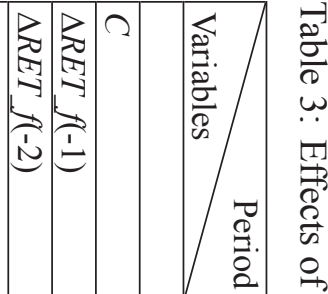

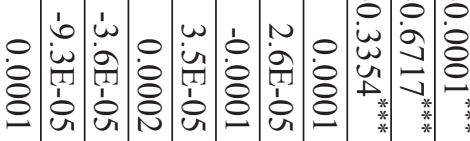

范

a * *

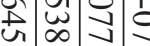

-

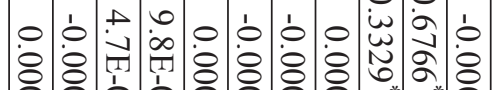

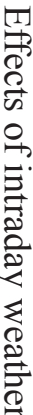

亏.

象

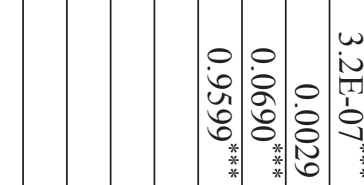

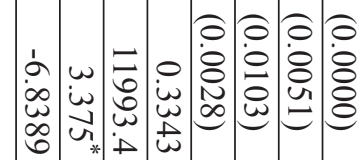

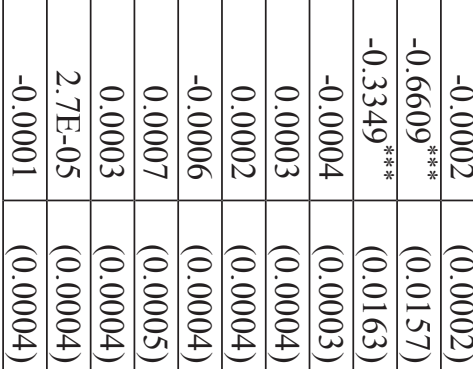

$\circ .0$

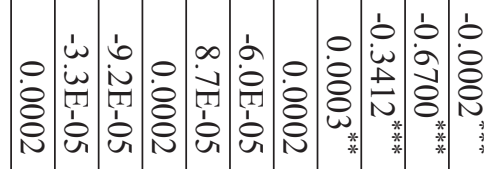

के

$* \overrightarrow{0}$ क

ㅂ. $\vec{\circ}$ के

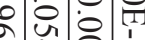

虫

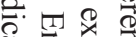

**** * * *

के वृ है

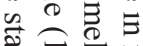

$\vec{\nabla} \cdot \overrightarrow{0}$

2. $\infty$

近的响

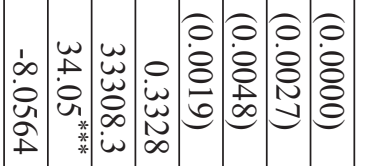

응 ô

ㅇㅇㅇㅇㅇㅇㅇㅇㅇㅇㅇㅇㅇㅇㅇㅇㅇㅇㅇㅇㅇㅇㅇ

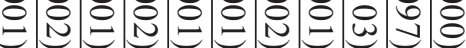

0
0
0
1
$\vdots$
$\vdots$
0.
0.
0
0
0
$\vdots$
0 
To strengthen the robustness of the results obtained with GJR-GARCH model, we also test the alternative GARCH models, such as the GARCH and EGARCH models. It is found that the direction and statistical significance of the estimated coefficients are fairly similar to those we obtained from the GJR-GARCH model, which lends support to our overall conclusion. The statistics representing the model-fitness also justify the use of the GJR-GARCH framework as the main model for this study.

Figure 1: Conditional variance series of the GJR-GARCH models

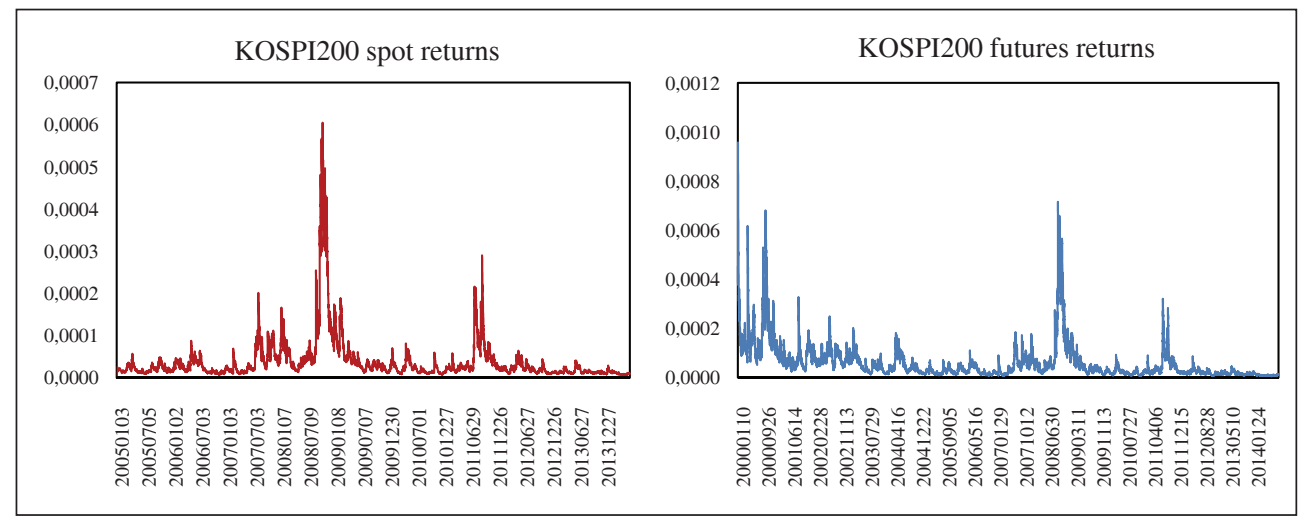

Note: This figure graphically presents the conditional variance series obtained from the regression results of the GJR-GARCH model for the KOSPI200 spot and futures returns.

Source: Authors' calculation

Figure 1 graphically presents the conditional variance series obtained from the regression results of the GJR-GARCH model for the KOSPI200 spot and futures returns. Both graphs in Figure 1 exhibit relatively high volatilities during 20082009 and 2011, when the financial markets experienced turmoil due to the global financial crisis and European debt crisis, respectively. These results reveal the phenomenon of volatility clustering, which suggests that high volatilities are often found to follow a period of high volatilities. 
Table 4: Effects of intraday weather changes on the probability of positive stock returns (Logit model)

Panel A. PrRET $k$

\begin{tabular}{|l|c|c|c|c|c|c|c|c|}
\hline \multirow{2}{*}{$\begin{array}{r}\text { Variables } \\
\text { Period }\end{array}$} & \multicolumn{2}{|c|}{ Whole Period } & \multicolumn{2}{|c|}{ Pre-crisis Period } & \multicolumn{2}{c|}{ During the Crisis } & \multicolumn{2}{c|}{ Post-crisis Period } \\
\hline $\mathrm{C}$ & $0.0528^{* *}$ & $(0.0212)$ & $0.1317^{* * *}$ & $(0.0373)$ & -0.0091 & $(0.0461)$ & 0.0218 & $(0.0311)$ \\
\hline $\mathrm{DH}_{\text {temp }}$ & 0.0096 & $(0.0553)$ & 0.1048 & $(0.1009)$ & 0.0886 & $(0.1195)$ & -0.078 & $(0.0798)$ \\
\hline $\mathrm{DH}_{\text {wind }}$ & 0.0215 & $(0.0548)$ & 0.0179 & $(0.0944)$ & -0.001 & $(0.1167)$ & 0.0264 & $(0.0829)$ \\
\hline $\mathrm{DH}_{\text {hum }}$ & -0.051 & $(0.0545)$ & -0.024 & $(0.0996)$ & -0.039 & $(0.1224)$ & -0.067 & $(0.0771)$ \\
\hline $\mathrm{DH}_{\text {ss }}$ & 0.0054 & $(0.0541)$ & 0.0743 & $(0.1021)$ & -0.012 & $(0.1221)$ & -0.011 & $(0.0754)$ \\
\hline $\mathrm{DL}_{\text {temp }}$ & $0.1096^{*}$ & $(0.0564)$ & -0.0677 & $(0.1122)$ & $0.3388^{* * *}$ & $(0.1231)$ & 0.1187 & $(0.0775)$ \\
\hline $\mathrm{DL}_{\text {wind }}$ & 0.0782 & $(0.0533)$ & -0.011 & $(0.1015)$ & $0.2655^{* *}$ & $(0.1241)$ & 0.0767 & $(0.0731)$ \\
\hline $\mathrm{DL}_{\text {hum }}$ & 0.0195 & $(0.0553)$ & $0.1974^{* *}$ & $(0.0991)$ & 0.0473 & $(0.1143)$ & -0.137 & $(0.0836)$ \\
\hline $\mathrm{DL}_{\text {ss }}$ & -0.026 & $(0.0530)$ & 0.0459 & $(0.0996)$ & -0.046 & $(0.1174)$ & -0.042 & $(0.0748)$ \\
\hline
\end{tabular}

Panel B. PrRET $f$

\begin{tabular}{|l|c|c|c|c|c|c|c|c|}
\hline \multirow{2}{*}{$\begin{array}{l}\text { Variables } \\
\text { Period }\end{array}$} & \multicolumn{2}{|c|}{ Whole Period } & \multicolumn{2}{|c|}{ Pre-crisis Period } & \multicolumn{2}{c|}{ During the Crisis } & \multicolumn{2}{c|}{ Post-crisis Period } \\
\hline$C$ & -0.016 & $(0.0169)$ & -0.017 & $(0.0229)$ & -0.016 & $(0.0461)$ & -0.019 & $(0.0302)$ \\
\hline $\mathrm{DH}_{\text {temp }}$ & $0.0739^{*}$ & $(0.0441)$ & 0.0905 & $(0.0604)$ & -0.0472 & $(0.1194)$ & 0.1002 & $(0.0772)$ \\
\hline $\mathrm{DH}_{\text {wind }}$ & -0.004 & $(0.0437)$ & -0.084 & $(0.0586)$ & 0.0861 & $(0.1172)$ & 0.1044 & $(0.0798)$ \\
\hline $\mathrm{DH}_{\text {hum }}$ & -0.019 & $(0.0439)$ & 0.0431 & $(0.0607)$ & 0.1142 & $(0.1229)$ & $-0.158^{* *}$ & $(0.0747)$ \\
\hline $\mathrm{DH}_{\text {ss }}$ & -0.031 & $(0.0434)$ & 0.0261 & $(0.0605)$ & -0.028 & $(0.1214)$ & -0.109 & $(0.0733)$ \\
\hline $\mathrm{DL}_{\text {temp }}$ & 0.0291 & $(0.0447)$ & -0.028 & $(0.0625)$ & $0.2203^{*}$ & $(0.1219)$ & 0.0491 & $(0.0756)$ \\
\hline $\mathrm{DL}_{\text {wind }}$ & -0.010 & $(0.0439)$ & $-0.128^{* *}$ & $(0.0626)$ & $0.2935^{* *}$ & $(0.1237)$ & 0.0440 & $(0.0718)$ \\
\hline $\mathrm{DL}_{\text {hum }}$ & -0.051 & $(0.0448)$ & 0.0042 & $(0.0609)$ & -0.069 & $(0.1140)$ & $-0.164^{* *}$ & $(0.0820)$ \\
\hline $\mathrm{DL}_{\text {ss }}$ & 0.0333 & $(0.0438)$ & 0.0321 & $(0.0625)$ & -0.036 & $(0.1172)$ & 0.0647 & $(0.0730)$ \\
\hline
\end{tabular}

Note: This table displays estimation results of the logit model. The dependent variables, PrRET_k (Panel A) and $\operatorname{PrRET} f$ (Panel B), denote the probabilities of positive KOSPI200 spot and futures returns, respectively. $D H_{\text {temp }}, D H_{\text {wind }}, D H_{\text {hum }}$, and $D H_{s s}\left(D L_{\text {temp }}, D L_{\text {wind }}\right.$, $D L_{\text {hum }}$, and $D L_{s s}$ ) are dummy variables of extremely high (extremely low) temperature, wind speed, humidity, and duration of sunshine, respectively. Standard errors are reported in parentheses. $*, * *$, and $* * *$ indicate statistical significance at the $10 \%, 5 \%$, and $1 \%$ levels, respectively.

Source: Authors' calculations

Table 4 presents the regression results of the logit model (Equation 3) to estimate the probability of positive stock returns in the event of unexpected weather conditions, using the KOSPI200 spot (Panel A) and futures (Panel B) returns. When tested over the whole sample period, statistically significant relations are found between extremely low temperature $\left(D L_{\text {temp }}\right)$ and positive spot returns, as well as between extremely high temperature $\left(D H_{\text {temp }}\right)$ and positive futures returns. Testing for the sub-periods also yields significant weather effects. 


\subsection{Effect of intraday weather changes on volatilities}

Tables 5 and 6 report the regression results of the OLS model assuming NeweyWest HAC standard errors and covariance, used in Equation (4), to analyze the intraday weather effects on stock market volatility. Table 5 reports the intraday results on the historical volatility of the KOSPI200 futures prices, and we find statistically significant weather effects of temperature and humidity.

Table 5: Effects of intraday weather changes on the historical volatility of KOSPI200 futures (OLS)

\begin{tabular}{|c|c|c|c|c|c|c|c|c|}
\hline $\begin{array}{l}\text { Period } \\
\text { Variables }\end{array}$ & \multicolumn{2}{|c|}{ Whole Period } & \multicolumn{2}{|c|}{ Pre-crisis Period } & \multicolumn{2}{|c|}{ During the Crisis } & \multicolumn{2}{|c|}{ Post-crisis Period } \\
\hline $\mathrm{C}$ & $0.0020^{* * *}$ & $(0.0001)$ & $0.0032^{* * *}$ & $(0.0001)$ & $0.0019^{* * *}$ & $(0.0002)$ & $0.0015^{* * *}$ & $(0.0001)$ \\
\hline$\Delta H L \_V O L(-1)$ & $0.4366^{* * *}$ & $(0.0143)$ & $0.3775^{* * * *}$ & $(0.0138)$ & $0.4687^{* * *}$ & $(0.0386)$ & $0.4092^{* * *}$ & (0.0116) \\
\hline$\triangle H L \_V O L(-2)$ & $0.2378^{* * *}$ & $(0.0107)$ & $0.1794^{* * *}$ & $(0.0125)$ & $0.2814^{* * *}$ & $(0.0311)$ & $0.2179^{* * *}$ & $(0.0116)$ \\
\hline $\mathrm{DH}_{\text {temp }}$ & $0.0006^{* * *}$ & $(0.0001)$ & $0.0006^{* * *}$ & $(0.0002)$ & $0.0008^{* *}$ & $(0.0004)$ & $0.0005^{* * *}$ & $(0.0001)$ \\
\hline $\mathrm{DH}_{\text {wind }}$ & $-4.8 \mathrm{E}-05$ & $(0.0000)$ & $-6.7 \mathrm{E}-05$ & $(0.0001)$ & $-1.9 \mathrm{E}-06$ & $(0.0002)$ & -0.0001 & $(0.0001)$ \\
\hline $\mathrm{DH}_{\text {hum }}$ & $0.0004^{* * *}$ & $(0.0001)$ & $0.0004^{* *}$ & $(0.0002)$ & $0.0007^{*}$ & $(0.0004)$ & 0.0003 & $(0.0001)$ \\
\hline $\mathrm{DH}_{\mathrm{ss}}$ & -0.0001 & $(0.0000)$ & -0.0001 & $(0.0001)$ & -0.0003 & $(0.0002)$ & $0.0001^{* * *}$ & $(0.0001)$ \\
\hline $\mathrm{DL}_{\text {temp }}$ & $0.0003^{* * *}$ & $(0.0000)$ & $0.0007^{* * *}$ & $(0.0001)$ & $7.9 \mathrm{E}-05$ & $(0.0003)$ & -0.0001 & $(0.0001)$ \\
\hline $\mathrm{DL}_{\text {wind }}$ & $-3.5 \mathrm{E}-05$ & $(0.0000)$ & $4.2 \mathrm{E}-05$ & $(0.0001)$ & 0.0004 & $(0.0003)$ & -0.0001 & $(0.0001)$ \\
\hline $\mathrm{DL}_{\text {hum }}$ & -0.0001 & $(0.0000)$ & $-0.0004^{* * *}$ & $(0.0001)$ & $-4.4 \mathrm{E}-05$ & $(0.0002)$ & -0.0001 & $(0.0001)$ \\
\hline $\mathrm{DL}_{\mathrm{ss}}$ & $-3.4 \mathrm{E}-05$ & $(0.0000)$ & $-6.7 \mathrm{E}-06$ & $(0.0002)$ & $-4.5 \mathrm{E}-05$ & $(0.0003)$ & 0.0001 & $(0.0001)$ \\
\hline$R^{2}$ & & 0.3694 & & 0.2431 & & 0.4777 & & 0.3153 \\
\hline
\end{tabular}

Note: This table displays the estimation results of the OLS model. The dependent variable, $H L$ $V O L$, denotes the historical volatility of the KOSPI200 futures. $D H_{\text {temp }}, D H_{\text {wind }}, D H_{\text {hum }}$, and $D H_{s s}\left(D L_{\text {temp }}, D L_{\text {wind }}, D L_{\text {hum }}\right.$, and $\left.D L_{s s}\right)$ are dummy variables for extremely high (extremely low) temperature, wind speed, humidity, and duration of sunshine, respectively. NeweyWest adjusted standard errors are reported in parentheses. *, **, and *** indicate statistical significance at the $10 \%, 5 \%$, and $1 \%$ levels, respectively.

Source: Authors' calculations

Across all sample and sub-sample periods, the results show that extremely high temperature and humidity increase the volatility. On the other hand, the overall results show that extremely low temperature (humidity) increases (decreases) the volatility.

Table 6 presents the results of the intraday weather effects on VKOSPI (the modelfree implied volatility index). 
Table 6: Effects of intraday weather changes on VKOSPI (OLS)

\begin{tabular}{|l|r|r|r|r|r|r|}
\hline \multirow{2}{*}{ Variables } & \multicolumn{2}{|c|}{ Whole Period } & \multicolumn{2}{c|}{ During the Crisis } & \multicolumn{2}{c|}{ Post-crisis Period } \\
\hline$C$ & 0.0472 & $(0.0325)$ & 0.0991 & $(0.0818)$ & 0.0705 & $(0.0434)$ \\
\hline$\Delta V K O S P I(-1)$ & $0.9258^{* * *}$ & $(0.0444)$ & $0.8523^{* * *}$ & $(0.0410)$ & $1.0757^{* * *}$ & $(0.0657)$ \\
\hline$\Delta V K O S P I(-2)$ & 0.0721 & $(0.0443)$ & $0.1451^{* * *}$ & $(0.0404)$ & -0.0796 & $(0.0660)$ \\
\hline $\mathrm{DH}_{\text {temp }}$ & 0.0114 & $(0.0272)$ & 0.0506 & $(0.0857)$ & -0.0082 & $(0.0200)$ \\
\hline $\mathrm{DH}_{\text {wind }}$ & $-0.0373^{*}$ & $(0.0220)$ & $-0.1060^{*}$ & $(0.0589)$ & -0.0072 & $(0.0178)$ \\
\hline $\mathrm{DH}_{\text {hum }}$ & 0.0157 & $(0.0243)$ & -0.0054 & $(0.0806)$ & 0.0243 & $(0.0182)$ \\
\hline $\mathrm{DH}_{\text {ss }}$ & -0.0129 & $(0.0186)$ & -0.0533 & $(0.0662)$ & 0.0031 & $(0.0130)$ \\
\hline $\mathrm{DL}_{\text {temp }}$ & 0.0110 & $(0.0211)$ & 0.0614 & $(0.0713)$ & -0.0044 & $(0.0116)$ \\
\hline $\mathrm{DL}_{\text {wind }}$ & -0.0062 & $(0.0230)$ & -0.0085 & $(0.0712)$ & 0.0012 & $(0.0194)$ \\
\hline $\mathrm{DL}_{\text {hum }}$ & -0.0225 & $(0.0264)$ & -0.1128 & $(0.0739)$ & 0.0118 & $(0.0148)$ \\
\hline $\mathrm{DL}_{\mathrm{ss}}$ & 0.0090 & $(0.0198)$ & 0.0380 & $(0.0594)$ & -0.0007 & $(0.0159)$ \\
\hline$R^{2}$ & & 0.9956 & & 0.9933 & & 0.9926 \\
\hline
\end{tabular}

Note: This table displays the estimation results of the OLS model. The dependent variable is VKOSPI. $D H_{\text {temp }}, D H_{\text {wind }}, D H_{\text {hum }}$, and $D H_{s s}\left(D L_{\text {temp }}, D L_{\text {wind }}, D L_{\text {hum }}\right.$, and $\left.D L_{s s}\right)$ are dummy variables for extremely high (extremely low) temperature, wind speed, humidity, and duration of sunshine, respectively. Newey-West adjusted standard errors are reported in parentheses. * and *** indicate statistical significance at the $10 \%$ and $1 \%$ levels, respectively.

Source: Authors' calculations

Compared to the effects on the historical volatility of the KOSPI200 futures prices (reported in Table 5), the weather effect in this case is shown to be much less significant.

\subsection{Robustness checks: hourly analyses and intraday patterns}

We conduct robustness checks by examining the effects of weather changes on stock returns and volatilities on an hourly basis; the regression results for these are presented in Tables 7 and 8. Pizzutilo and Roncone (2016) conjecture that if the weather conditions can influence investor behavior or their risk preference, the magnitude of these effects on the stock market would vary according to the time of the day. For example, humans are more susceptible to weather conditions at the beginning of the working day than towards its end, and the mood of a person can vary owing to many other factors and the new market information received. In addition, given that most people work inside buildings, they have low exposure to external environmental conditions in the middle of the working day. To this end, they point out a bias in weather effect analyses conducted on a daily basis, which is the case for the majority of extant research. Therefore, we sub-divide our sample data into hourly observations, and carry out the regression on an hourly basis to investigate any specific hourly effects of weather conditions on the returns (Table 7) and volatilities (Table 8).

Table 7 shows that there are few significant parameter estimates for the hourly observations from 11:00 and 15:00 of both the KOSPI200 spot and futures returns. 


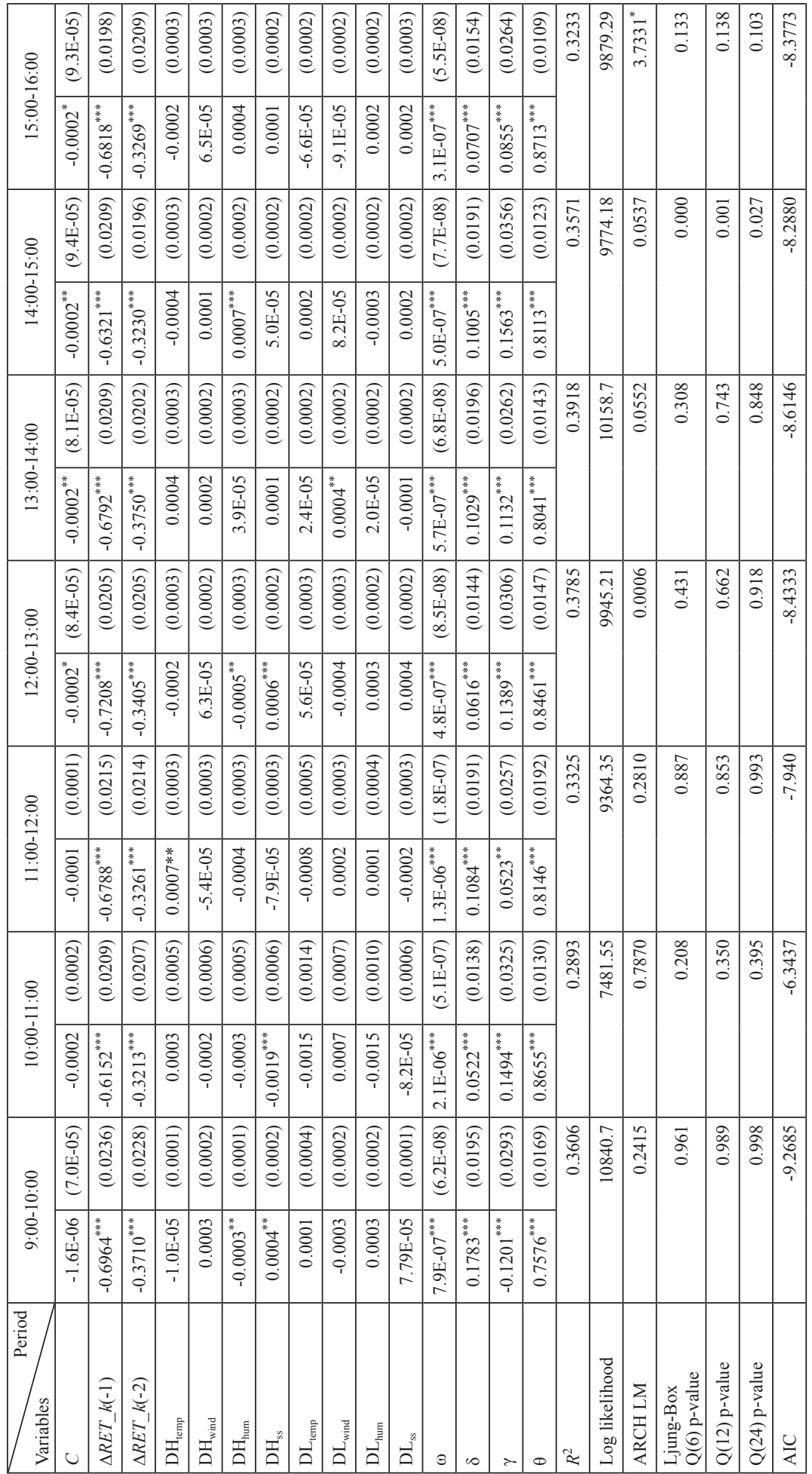


Hyein Shim, Maria H. Kim, Doojin Ryu • Effects of intraday weather changes on asset... Zb. rad. Ekon. fak. Rij. • $2017 \cdot$ vol. $35 \cdot$ no. $2 \cdot 301-330$

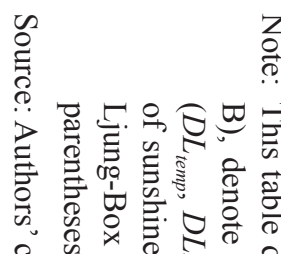

\%

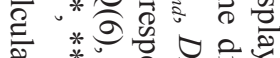

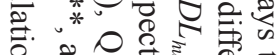

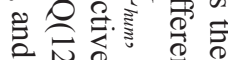
* 눈 *

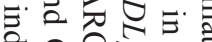

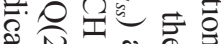

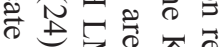

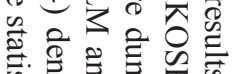

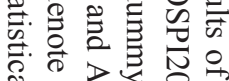

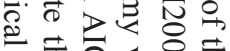

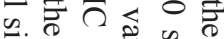

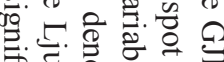

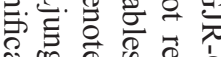

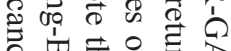

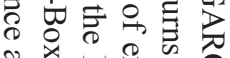

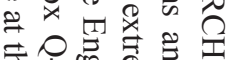

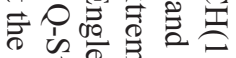

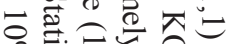
일.

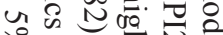
$\because \nRightarrow \omega$

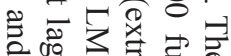
न人䧄 - 0

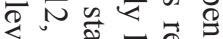
क 然. 造

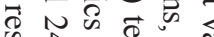
若

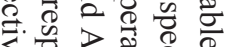
क 을. 랑

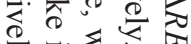
㧒 पn एक 훙 ○ᄋ它芯

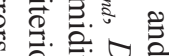

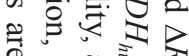

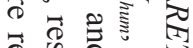
용 융 党.

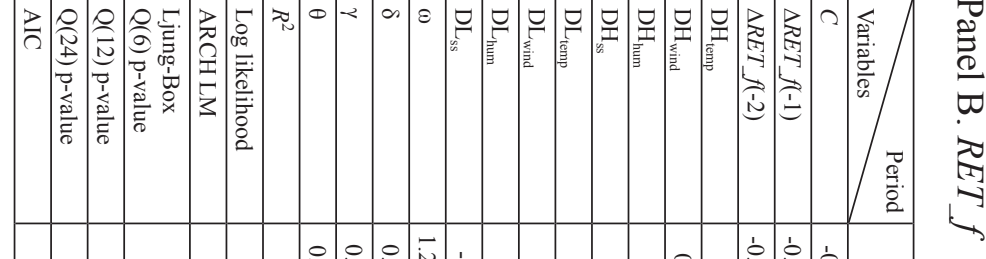

a 0 J

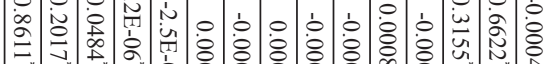

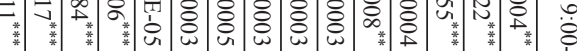

岕

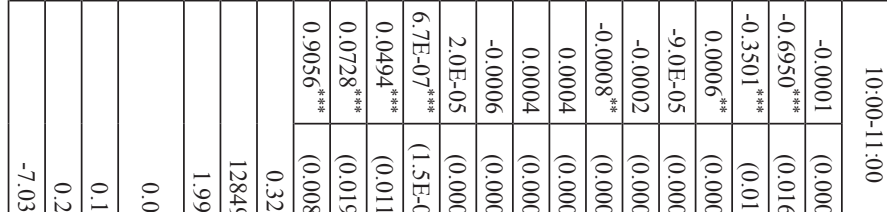

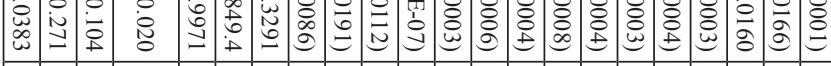

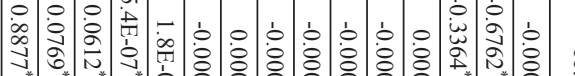

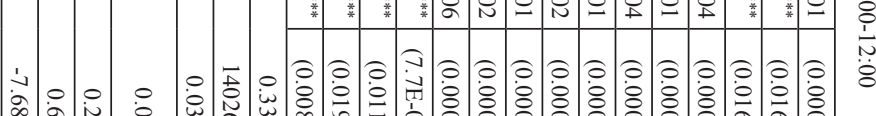
市

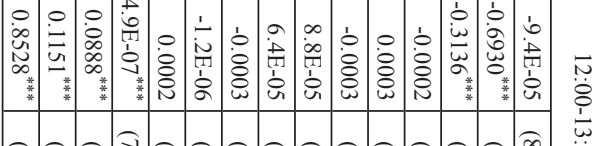

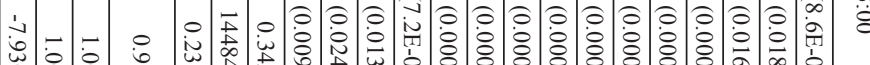

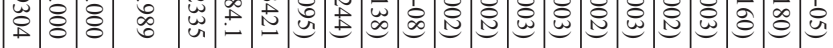

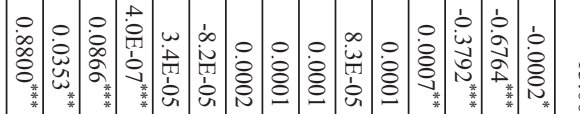

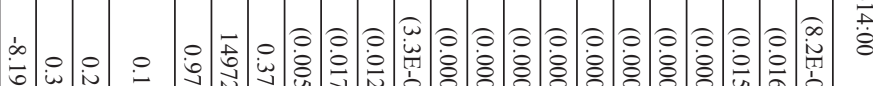
点

\begin{tabular}{|c|c|c|c|c|c|c|c|c|c|c|c|c|c|}
\hline & & & 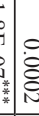 & $\begin{array}{l}\infty \\
\infty \\
+1 \\
1 \\
\vdots \\
\vdots\end{array}$ & 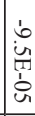 & 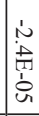 & $\begin{array}{l}\dot{b} \\
\dot{\omega} \\
\underline{1} \\
\dot{b} \\
\dot{v}\end{array}$ & $\mid \begin{array}{c}0 \\
0 \\
8 \\
8 \\
0 \\
-4 \\
* \\
* \\
*\end{array}$ & 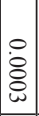 & $\begin{array}{l}1 \\
\dot{0} \\
\dot{0} \\
0 \\
\text { un }\end{array}$ & $\begin{array}{c}\dot{0} \\
\dot{N} \\
\mathbb{N} \\
\underbrace{}_{*} \\
\vdots \\
*\end{array}$ & & $\begin{array}{l}1 \\
0 \\
8 \\
8 \\
\end{array}$ \\
\hline & & & 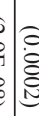 & 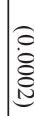 & $\begin{array}{l}0 \\
0 \\
8 \\
0 \\
0\end{array}$ & $\begin{array}{l}0 \\
\dot{\delta} \\
\dot{\delta}\end{array}$ & $\begin{array}{l}\text { Oे } \\
\dot{8} \\
\text { ¿̊․ }\end{array}$ & 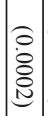 & 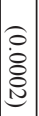 & $\begin{array}{l}0 \\
0 \\
\dot{0} \\
0 \\
ن\end{array}$ & $\begin{array}{l}\hat{0} \\
\stackrel{0}{\prime} \\
\stackrel{\omega}{\infty} \\
\infty\end{array}$ & $\begin{array}{l}\hat{\sigma} \\
\hat{\sigma} \\
\hat{\sigma}\end{array}$ & 13 \\
\hline & & & 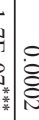 & $\begin{array}{l}\dot{n} \\
\dot{1} \\
1 \\
\dot{u} \\
u\end{array}$ & 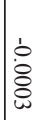 & $\begin{array}{l}1 \\
\dot{8} \\
0 \\
0\end{array}$ & $\begin{array}{l}\hat{a} \\
\hat{\tilde{T}} \\
\dot{1} \\
\dot{u}\end{array}$ & $\begin{array}{l}0 \\
\dot{8} \\
\vdots \\
\dot{1}\end{array} \mid$ & 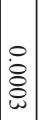 & 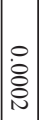 & \begin{tabular}{|l|}
$\dot{1}$ \\
$\dot{\omega}$ \\
$\tilde{N}$ \\
$\dot{O}_{*}$ \\
$*$
\end{tabular} & $\begin{array}{c}\vec{a} \\
\vec{A}_{*} \\
\frac{*}{*}\end{array}$ & ن̀ \\
\hline & & & 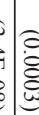 & $?$ & 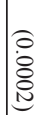 & $\begin{array}{l}0 \\
0 \\
\dot{8} \\
\stackrel{8}{0}\end{array}$ & 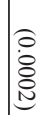 & 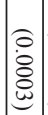 & 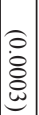 & $\mid$\begin{tabular}{|c|}
0 \\
$\dot{0}$ \\
$\dot{0}$ \\
$\dot{0}$ \\
$ن$
\end{tabular} & $\begin{array}{l}\hat{\partial} \\
\text { Oे } \\
\text { बे }\end{array}$ & & 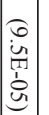 \\
\hline
\end{tabular}


Hyein Shim, Maria H. Kim, Doojin Ryu • Effects of intraday weather changes on asset...

Using the GJR-GRACH model to find the hourly weather effects, there is little evidence of residual ARCH effects in the KOSPI200 spot and futures returns except the 15:00-16:00 window. Further, the serial correlation is not found in the squared residuals of the KOSPI200 spot and futures returns except the 14:00-15:00 window.

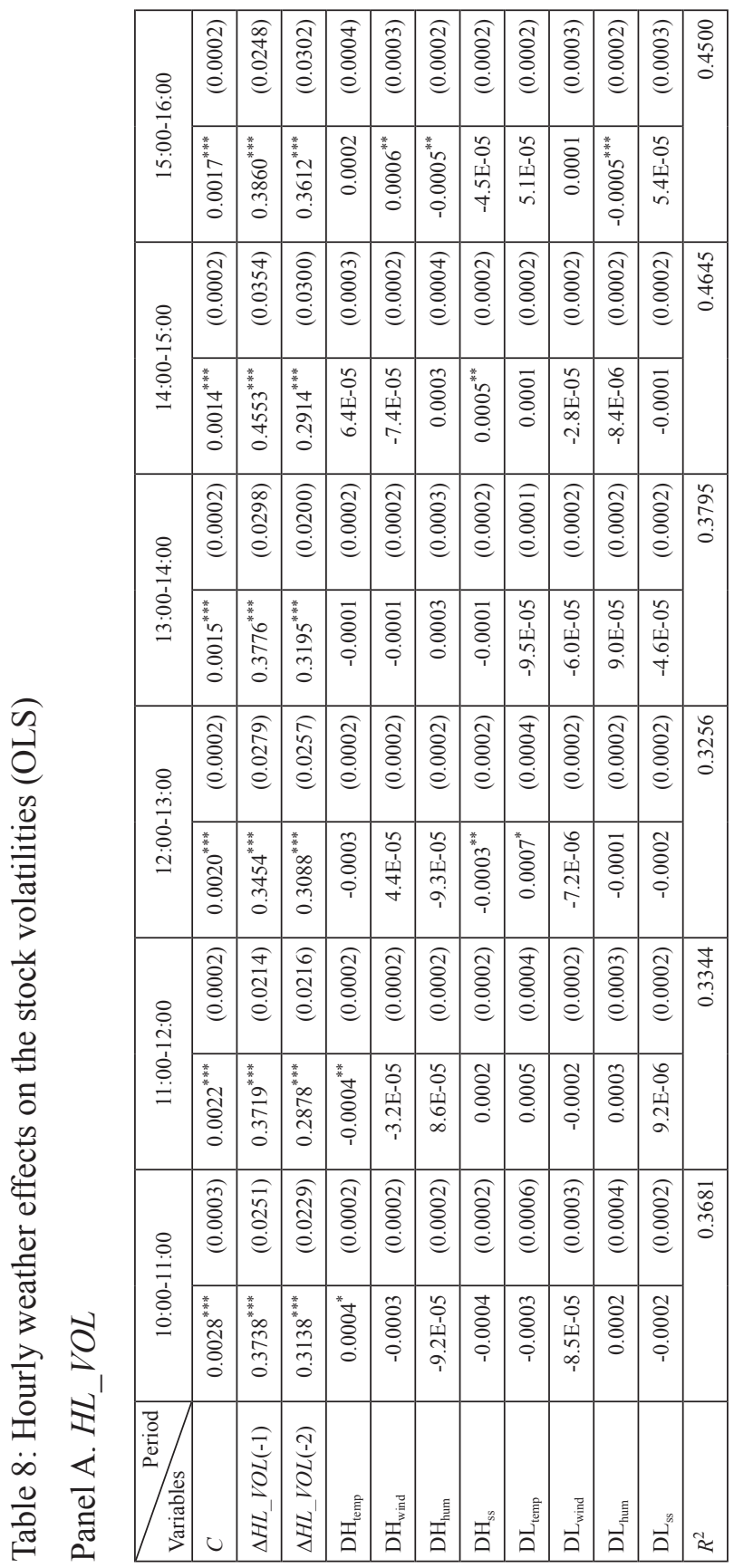




है चे

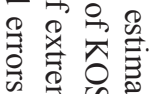

$\because$ 芯芯.

$\overrightarrow{0} 87$

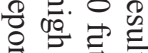

त用吉

裉。

卷言

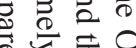

总它产的

焉主文

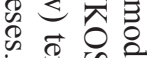

* 寻五?

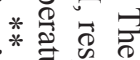

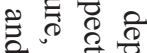

$\leq$.

*

.

․ㅠ.

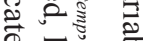

声

善.

言. 窎

ङ

ต.

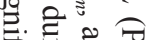

志芯芯

है

$\because 0$ 零

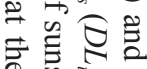

(c)

유유

u 0 焉

○ำ

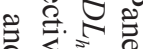

2.

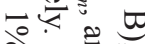

○艺。

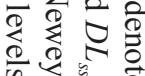

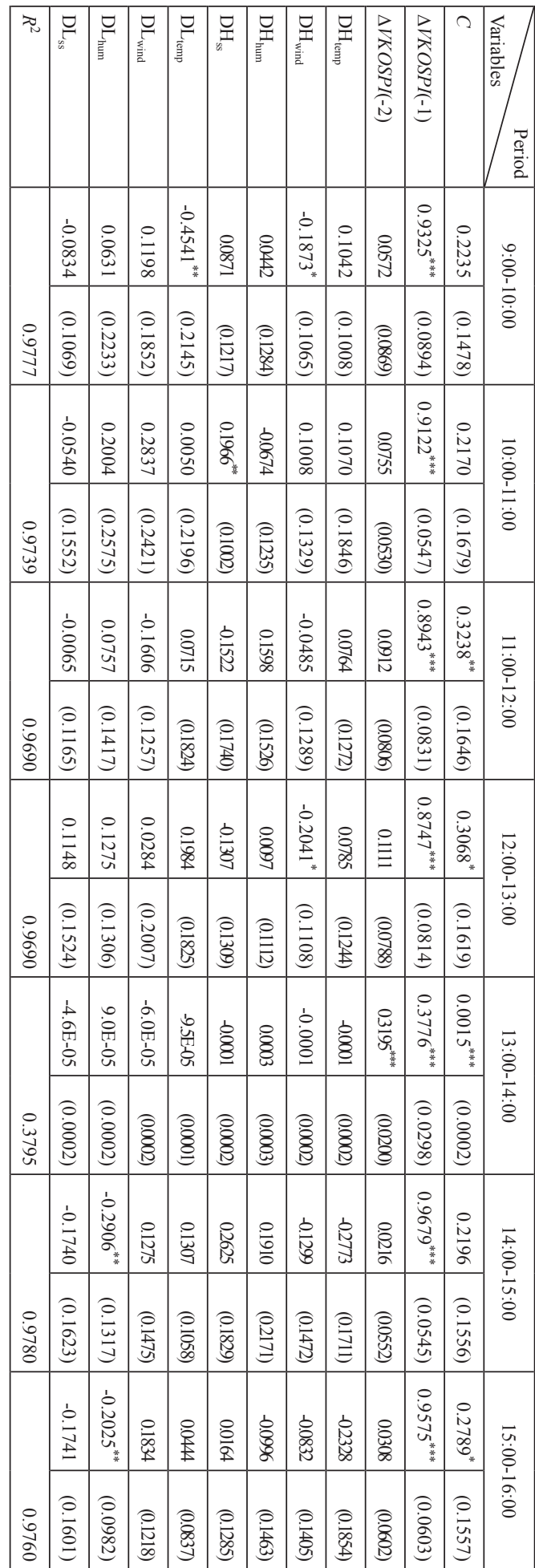

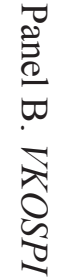




\section{Results and discussion}

Our intraday analyses on the spot market show that extreme temperatures, whether high or low, are likely to increase the difference in returns (Table 2), indicating that the extreme weather condition significantly affects the investor sentiment and mood of stock market participants. Though we conjecture that the KOSPI200 futures market would exhibit the weather effect because of its idiosyncratic characteristic of being sensitive to investor sentiments, only extremely high temperature affects the futures market dynamics in the post-crisis period (Table 3). This indicates the relatively better information efficiency of the futures market, compared to the underlying spot market.

It is noted that both the KOSPI200 spot and futures returns are more sensitive to extremely low weather conditions than extremely high weather conditions (Table 4). This indicates that the probability of positive stock returns can be disproportionately dominated by extreme weather conditions. The results in Table 5 indicate that both extremely high and low temperatures make the financial market significantly more volatile, whereas the humidity is positively associated with the historical change in volatility. According to the psychologists, temperature has a substantial influence on individuals' moods, particularly when they are exposed to severe heat or cold. They posit that people tend to feel less comfortable and more fatigued by extreme temperatures, and find that the level of humidity is inversely related to individuals' happiness and vitality (Denissen et al., 2008; Sanders and Brizzolara, 1982). Our results in Table 5, showing a strong correlation between market risk and extremely high temperature and humidity support the aforementioned findings in the psychology literature.

The weaker intraday weather effect on the implied volatility (Table 6) than on the historical volatility (Table 5) can be attributed to the different characteristics of historical and implied volatilities. It should be noted that the purpose of the analysis on the weather effect on the historical volatility is to capture investor sensitivity to information during changes in weather conditions. On the other hand, the analysis on the implied volatility is intended to explain how changes in weather conditions affect investors' expectations/forecasts of the future volatility of the market (Shim et al., 2015). The above result could also be attributed to the VKOSPI's relatively short history. The time-series data of the VKOSPI prior to its first trading day in April 2009 had to be derived using the historical observations. Despite the overall insignificance of our estimation using the VKOSPI data, Table 6 indicates that extremely high wind speeds can reduce the market risk.

The hourly analyses in Tables 7 and 8 also yield some interesting findings. Given that 11:00 and 15:00 are well after the market opening time and lunch break, respectively, the insignificant weather effect on returns during this interval (Table 7) appears to support the argument of Pizzutilo and Roncone (2016). Meanwhile, 
statistically significant results indicate that the difference in the returns responds more sensitively to extreme (high rather than low) weather conditions. Compared to the results found in Table 2, where difference of the KOSPI200 returns is shown to be significantly affected by the unexpected changes in temperature, the hourly analysis reveals that the humidity and length of sunshine are the major factors responsible for the difference in the KOSPI200 returns.

The significant weather effects on volatilities (Table 8) for hourly intraday intervals indicate the presence of weather effects on the volatilities during most of the working day except during the lunch break, that is between 12:00 and 13:00, given that the volatility value at time $t$ is computed using the price data observations recorded at one-minute intervals from $t-1$ to one minute prior to time $t$. It is also notable that the volatilities are affected by both extreme (high and low) weather conditions, a result that disagrees with the stock return results reported in Table 7.

Our overall analyses suggest the presence of intraday weather effects in an emerging financial market, which counters the notion of market efficiency. The territory of South Korea is not large and its population is concentrated in a few large cities that share almost the same type of climate. The majority of active investors in the South Korean financial markets are individual investors, whose investment behavior/decisions are susceptible to their emotional/sentimental dynamics. Therefore, choosing the South Korean financial market as a study object is ideal for investigating the weather effect on investor sentiment problems. We provide a detailed comparative analysis of the effects of weather conditions on the morning and midday trading windows to make the research results more robust.

Our empirical results suggest that the trading decisions of investors are affected by investors' mood and sentiment. Analyzing the sentiment influencers, traders can benefit from their customized investment strategies, and it is suggested that policy makers should acknowledge the presence of market irregularity and investor irrationality.

\section{Conclusions}

In this study, we examine the intraday weather effect on the Korean financial markets with the following objectives in mind: $i$ ) determine if weather conditions are idiosyncratic determinants causing anomalous behavior at specific market locations; ii) assess if the weather affects trading activities other than asset returns, and iii) verify if the weather effect is time-specific. This study makes three distinctive contributions to the literature. First, using intraday weather and market data we re-examine the correlation between weather and the financial market; this is not possible by using daily observations. Second, we investigate the weather effect on market volatilities as well as market returns. Third, we 
provide empirical evidence of weather effect on the leading emerging market, where individual investors who are easily affected by sentiment and behavioral biases are the dominant market participants. Given the market's size and its unique framework, these empirical results are of economic value and have significant implications.

The following are the notable findings of this study. First, we document a modest presence of the weather effect on stock returns in the Korean financial market. In particular, the KOSPI200 returns are significantly influenced by unexpected changes in temperature, and both extremely high and extremely low temperatures increase the difference in the returns. In addition, we find that positive KOSPI200 returns are likely to be greatly affected by extremely low temperature. Second, the historical volatility of the KOSPI200 futures is subject to changes in temperature and humidity. This finding supports the psychologists' proposition that temperature, especially extremely low or extremely high temperature, significantly affects people's moods and that humidity negatively affects individuals' happiness and vitality. Third, the hourly analysis of the weather effect on the returns and volatilities indicates that the further away the trading hour from the exposure to the external environment (i.e., the further the hour from the beginning of the working day or from the lunch break), the lower the statistical significance of the weather effect. In addition, compared to the use of daily observations, the use of intraday hourly observations provides different results with regard to the significance of the weather effect; this indicates the presence of hourly weather effects on the Korean stock market.

Our study suggests that the weather affects asset price dynamics via investor mood and sentiment in the leading emerging market. Though we analyze the rich information contained in the Korean market trading dataset, the single-market study is a major limitation. Future research may adopt the cross-market approach and consider overseas market shocks and/or the investor sentiment of foreign investors. It should also compare the empirical results of developed and emerging markets.

\section{References}

Ahn, H-.J., Kang, J., Ryu, D. (2008). "Informed trading in the index option market: The case of KOSPI 200 options", Journal of Futures Markets, Vol. 28, No. 12, pp. 1118-1146, doi: 10.1002/fut.20369.

Bagozzi, R.P., Gopinath, M., Nyer, P.U. (1999). "The role of emotions in marketing", Journal of the Academy of Marketing Science, Vol. 27, No. 2, pp. 184-206, doi: 10.1177/0092070399272005.

Baker, M., Stein, J.C. (2004). "Market liquidity as a sentiment indicator", Journal of Financial Markets, Vol. 7, No. 3, pp. 271-299, doi: 10.1016/j.finmar.2003.11.005. 
Baker, M., Wurgler, J. (2006). "Investor sentiment and the cross-section of stock returns", Journal of Finance, Vol. 61, No. 4, pp. 1645-1680, doi: 10.1111/j.1540-6261.2006.00885.x.

Baker, M., Wurgler. J., Yuan, Y. (2012). "Global, local and contagious investor sentiment”, Journal of Financial Economics, Vol. 104, pp. 272-287, doi: 10.1016/j.jfineco.2011.11.002.

Black, F. (1986). "Noise", Journal of Finance, Vol. 41, No. 3, pp. 528-543, doi: 10.1111/j.1540-6261.1986.tb04513.x.

Brown, G.W. (1999). "Volatility, sentiment, and noise traders", Financial Analysts Journal, Vol. 55, No. 2, pp. 82-90, doi: 10.2469/faj.v55.n2.2263.

Cao, M., Wei, J. (2005). "Stock market returns: A note on temperature anomaly", Journal of Banking \& Finance, Vol. 29, No. 6, pp. 1559-1573, doi: 10.1016/j. jbankfin.2004.06.028.

Chang, S-.C. et al. (2008). "Weather and intraday patterns in stock returns and trading activity", Journal of Banking \& Finance, Vol. 32, No. 9, pp. 1754-1766, doi: 10.1016/j.jbankfin.2007.12.007.

Chang, T. et al. (2006). "Are stock market returns related to the weather effects? Empirical evidence from Taiwan", Physica A: Statistical Mechanics and its Applications, Vol. 364, pp. 343-354, doi: 10.1016/j.physa.2005.09.040.

Chung, K.H., Park, S.G., Ryu, D. (2016). "Trade duration, informed trading, and option moneyness", International Review of Economics and Finance, Vol. 44, pp. 395-411, doi: 10.1016/j.iref.2016.02.003.

Cornett, M.M. et al. (2011). "Liquidity risk management and credit supply in the financial crisis", Journal of Financial Economics, Vol. 101, No. 2, pp. 297-312, doi: 10.1016/j.jfineco.2011.03.001.

Denissen, J.J.A. et al. (2008). "The effects of weather on daily mood: A multilevel approach", Emotions, Vol. 8, No. 5, 662-667, doi: 10.1037/a0013497.

Dowling, M., Lucey, B.M. (2005). "Weather, biorhythms, beliefs and stock returns - some preliminary Irish evidence", International Review of Financial Analysis, Vol. 14, No. 3, pp. 337-355, doi: 10.1016/j.irfa.2004.10.003.

Dowling, M., Lucey, B.M. (2008). "Mood and UK equity pricing", Applied Financial Economics Letters, Vol. 4, No. 4, pp. 233-240, doi: 10.1080/17446540701720584.

Engle, R.F. (1982). "Autoregressive conditional heteroscedasticity with estimates of the variance of United Kingdom inflation”, Econometrica, Vol. 50, No. 4, pp. 987-1007, doi: 10.2307/1912773.

Fama, E.F. (1970). "Efficient capital markets: A review of theory and empirical work", Journal of Finance, Vol. 25, No. 2, pp. 383-417, doi: 10.1111/j.1540-6261.1970. tb00518.x.

Floros, C. (2011). "On the relationship between weather and stock market returns", Studies in Economics and Finance, Vol. 28, No. 1, pp. 5-13, doi: $10.1108 / 10867371111110525$. 
Goetzmann, W.N., Zhu, N. (2005). "Rain or shine: where is the weather effect?", European Financial Management, Vol. 11, No. 5, pp. 559-578, doi: 10.1111/j.1354-7798.2005.00298.x.

Hirshleifer, D., Shumway, T. (2003). "Good day sunshine: Stock returns and the weather", Journal of Finance, Vol. 58, No. 3, pp. 1009-1032, doi: 10.1111/15406261.00556 .

Isen, A.M. et al. (1978). "Affect, accessibility of material in memory, and behavior: A cognitive loop?", Journal of Personality and Social Psychology, Vol. 36, No. 1, pp. 1-12, doi: 10.1037/0022-3514.36.1.1.

Jacobsen, B., Marquering, W. (2008). "Is it the weather?", Journal of Banking \& Finance, Vol. 32, No. 4, pp. 526-540, doi: 10.1016/j.jbankfin.2007.08.004.

Johnson, E.J., Tversky, A. (1983). "Affect, generalization, and the perception of risk", Journal of Personality and Social Psychology, Vol. 45, No. 1, pp. 20-31, doi: 10.1037/0022-3514.45.1.20.

Kahneman, D., Riepe, M.W. (1998). "Aspects of investor psychology", Journal of Portfolio Management, Vol. 24, No. 4, pp. 52-65, doi: 10.3905/jpm.1998.409643.

Kahneman, D., Tversky, A. (1973). "On the psychology of prediction", Psychological Review, Vol. 80, No. 4, pp. 237-251, doi: 10.1037/h0034747.

Kamstra, M. J., Kramer, L. A., Levi, M.D. (2003). "Winter blues: A SAD stock market cycle", American Economic Review, Vol. 93, No. 1, pp. 324-343, http:// www.jstor.org/stable/3132178.

Kang, S.H. et al. (2010). "Weather effects on the returns and volatility of the Shanghai stock market", Physica A: Statistical Mechanics and its Applications, Vol. 389, No. 1, pp. 91-99, doi: 10.1016/j.physa.2009.09.010.

Keef, S.P., Roush, M.L. (2002). "The weather and stock returns in New Zealand", Quarterly Journal of Business and Economics, Vol. 41, No. 1/2, pp. 61-79, http://www.jstor.org/stable/40473345.

Keef, S.P., Roush, M.L. (2007a). "A meta-analysis of the international evidence of cloud cover on stock returns", Review of Accounting and Finance, Vol. 6, No. 3, pp. 324-338, doi: 10.1108/14757700710778045.

Keef, S.P., Roush, M.L. (2007b). "Daily weather effects on the returns of Australian stock indices", Applied Financial Economics, Vol. 17, No. 3, pp. 173-184, doi: 10.1080/09603100600592745.

Kim, J.S., Ryu, D., Seo, S.W. (2014). "Investor sentiment and return predictability of disagreement", Journal of Banking and Finance, Vol. 42, pp. 166-178, doi: 10.1016/j.jbankfin.2014.01.017.

Kim, J.S., Ryu, D., Seo, S.W. (2015). "Corporate vulnerability index as a fear gauge? Exploring the contagion effect between U.S. and Korean markets", Journal of Derivatives, Vol. 23, No. 1, pp. 73-88, doi: 10.3905/jod.2015.23.1.073.

Krämer, W., Runde, R. (1997). "Stocks and the weather: An exercise in data mining or yet another capital market anomaly?", Empirical Economics, Vol. 22, No. 4, pp. 637-641, doi: 10.1007/BF01205784. 
Kyle, A.S. (1985). "Continuous auctions and insider trading", Econometrica, Vol. 53, No. 6, pp. 1315-1335, doi: 10.2307/1913210.

Lee, J., Ryu, D., Kutan A.M. (2016). "Monetary policy announcements, communication, and stock market liquidity", Australian Economic Papers, Vol. 55, No. 3, pp. 227-250, doi: 10.1111/1467-8454.12069.

Loewenstein, G.F. et al. (2001). "Risk as feelings", Psychological Bulletin, Vol. 127, No. 2, pp. 267-286, doi: 10.1037/0033-2909.127.2.267.

Lu, J., Chou, R.K. (2012). "Does the weather have impacts on returns and trading activities in order-driven stock markets? Evidence from China", Journal of Empirical Finance, Vol. 19, No. 1, pp. 79-93, doi: 10.1016/j.jempfin.2011.10.001.

Mayer, J.D., Hanson, E. (1995). "Mood-congruent judgment over time”, Personality and Social Psychology Bulletin, Vol. 21, No. 3, pp. 237-244, doi: 10.1177/ 0146167295213005.

Mian, A., Sufi, A. (2009). "The consequences of mortgage credit expansion: Evidence from the U.S. mortgage default crisis", Quarterly Journal of Economics, Vol. 124, No. 4, pp. 1449-1496, doi: 10.1162/qjec.2009.124.4.1449.

Mian, A., Sufi, A., Trebbi, F. (2010). "The political economy of the US mortgage default crisis", American Economic Review, Vol. 100, No. 5, pp. 1967-1998, doi: 10.1257/aer.100.5.1967.

Nasby, W., Yando, R. (1982). Selective encoding and retrieval of affectively valent information: two cognitive consequences of children's mood states", Journal of Personality and Social Psychology, Vol. 43, No. 6, pp. 1244-1253, doi: 10.1037/0022-3514.43.6.1244.

Nissim, B.D., Liran, L., Eshel, S. (2012). "Do natural phenomena affect stocks' yield in Israel?", Applied Financial Economics, Vol. 22, No. 2, pp. 127-133, doi: 10.1080/09603107.2011.605753.

Park S.Y., Ryu, D., Song, J. (2017). "The dynamic conditional relationship between stock market returns and implied volatility", Physica A: Statistical Mechanics and its Applications, Vol. 482, pp. 638-648, doi: 10.1016/j.physa.2017.04.023.

Pizzutilo, F., Roncone, V. (2016). "Red sky at night or in the morning, to the equity market neither a delight nor a warning: the weather effect re-examined using intraday stock data", European Journal of Finance, 1-31, doi: 10.1080/ 1351847X.2016.1151808.

Reinhart, C.M., Rogoff, K.S. (2008). "Is the 2007 US sub-prime financial crisis so different? An international historical comparison", American Economic Review, Vol. 98, No. 2, pp. 339-344, doi: 10.1257/aer.98.2.339.

Rose, A.K., Spiegel, M.M. (2012). "Cross-country causes and consequences of the 2008 crisis: Early warning", Japan and the World Economy, Vol. 24, No. 1, pp. 1-16, doi: 10.1016/j.japwor.2011.11.001.

Ryu, D. (2011). "Intraday price formation and bid-ask spread components: A new approach using a cross-market model", Journal of Futures Markets, Vol. 31, No. 12, pp. 1142-1169, doi: 10.1002/fut.20533. 
Ryu, D., Kim, H., Yang, H. (2017). "Investor sentiment, trading behavior and stock returns", Applied Economics Letters, Vol. 24, No. 12, pp. 826-830, doi: 10.1080/13504851.2016.1231890.

Ryu, D., Ryu, D., Hwang, J.H. (2017). “Corporate governance, product-market competition, and stock returns: evidence from the Korean market", Asian Business and Management, Vol. 16, No. 1-2, pp. 50-91, doi: 10.1057/s41291017-0014-6.

Sanders, J.L., Brizzolara, M.S. (1982). "Relationships between weather and mood", Journal of General Psychology, Vol. 107, No. 1, pp. 155-156, doi: 10.1080/ 00221309.1982 .9709917$.

Saunders, E.M. (1993). "Stock prices and Wall Street weather", American Economic Review, Vol. 83, No. 5, pp. 1337-1345, http://www.jstor.org/stable/2117565.

Schwarz, N., Clore, G.L. (1983). "Mood, misattribution, and judgments of wellbeing: Informative and directive functions of affective states", Journal of Personality and Social Psychology, Vol. 45, No. 3, pp. 513-523, doi: 10.1037/0022-3514.45.3.513.

Shim, H., Kim, H., Kim, J.Y., Ryu, D. (2015). "Weather and stock market volatility: the case of a leading emerging market", Applied Economics Letters, Vol. 22, No. 12, pp. 987-992, doi: 10.1080/13504851.2014.993129.

Sim, M., Ryu, D., Yang, H. (2016). "Tests on the monotonicity properties of KOSPI 200 options prices", Journal of Futures Markets, Vol. 36, No. 7, pp. 625-646, doi: 10.1002/fut.21763.

Song, W., Ryu, D., Webb R.I. (2016). "Overseas market shocks and VKOSPI dynamics: A Markov-switching approach", Finance Research Letters, Vol. 16, pp. 275-282, doi: 10.1016/j.frl.2015.12.007.

Symeonidis, L., Daskalakis, G., Markellos, R.N. (2010). "Does the weather affect stock market volatility?”, Finance Research Letters, Vol. 7, No. 4, pp. 214-223, doi: 10.1016/j.frl.2010.05.004

Trombley, M.A. (1997). "Stock prices and Wall Street weather: Additional evidence", Quarterly Journal of Business and Economics, Vol. 36, No. 3, pp. 11-21, http://www.jstor.org/stable/40473319.

Wright, W.F., Bower, G.H. (1992). "Mood effects on subjective probability assessment", Organizational Behavior and Human Decision Processes, Vol. 52, No. 2, pp. 276-291, doi: 10.1016/0749-5978(92)90039-A.

Yang, H., Choi, H-.S., Ryu, D. (2017a). "Option market characteristics and price monotonicity violations", Journal of Futures Markets, Vol. 37, No. 5, pp. 473498, doi: 10.1002/fut.21826.

Yang H., Ryu, D., Ryu, D. (2017b). "Investor sentiment, asset returns and firm characteristics: Evidence from the Korean stock market", Investment Analysts Journal, Vol, 46. No. 2, pp. 132-147, doi: 10.1080/10293523.2016.1277850. 
Yoon, S.M., Kang, S.H. (2009). "Weather effects on returns: Evidence from the Korean stock market", Physica A: Statistical Mechanics and its Applications, Vol. 388, No. 5, pp. 682-690, doi: 10.1016/j.physa.2008.11.017.

\title{
Utjecaj unutar-dnevnih vremenskih promjena na povrat ulaganja i volatilnost ${ }^{1}$
}

\author{
Hyein Shim ${ }^{2}$, Maria H. Kim ${ }^{3}$, Doojin Ryu ${ }^{4}$
}

\begin{abstract}
Sažetak
Analizirajući unutar-dnevni skup podataka o informacijama o vremenu $i$ tržištu korištenjem proširenog GJR-GARCH okvira, ova studija detaljno istražuje vremenske učinke na profitabilnost $i$ volatilnost tržišta korejskih dionica i derivata. Naše unutar-dnevne analize pridonose postojećoj literaturi tako da nadilaze pokušaje prethodnih studija da bilježe vremenske utjecaje koristeći samo prosječne dnevne opservacije. Empirijski rezultati dokazuju skromnu prisutnost vremenskog utjecaja na prinose $i$ volatilnost, iako je značaj vremenskog utjecaja različit $u$ različitim tržišnim uvjetima $i$ indeksima. Također smo ustanovili da prinosi $i$ volatilnost asimetrično reagiraju na iznimno dobre i loše vremenske uvjete. Unutar-dnevne analize pokazuju da je vremenski utjecaj na prinose $i$ volatilnost statistički značajniji početkom radnog dana ili pauze za ručak, što ukazuje na postojanje unutar-dnevnih vremenskih učinaka na financijsko tržište.
\end{abstract}

Ključne riječi: povrat ulaganja, bihevioralne financije, GJR-GARCH, unutar-dnevna analiza, vremenski učinak, volatilnost

JEL klasifikacija: G02, G14, G15

1 Ovo istraživanje je financirano od strane Ministarstva obrazovanja Republike Koreje i Korejske nacionalne zaklade za znanost [NRF-2017S1A5A2A01025583].

2 Doktor ekonomskih znanosti, istraživač, Korea Public Finance Information Service, Metrotower, 10, Toegye-ro, Jung-gu, Seoul, 04637, Republika Koreja. Znanstveni interes: makroekonomija, javne financije, ekonometrija. Tel.: +82 26908 8568. Fax: +82 26312 8959. E-mail: hyein@ kpfis.kr.

3 Doktorica ekonomskih znanosti, predavačica, University of Wollongong, Northfields Avenue, Wollongong, New South Wales 2522, Australija. Znanstveni interes: modeliranje predstanja bankrota, modeliranje rizika kreditnog rejtinga, korporativno upravljanje, upravljanje zaradama. Tel.: +612 4221 4759.Fax:+61242214297.E-mail: mhykim@uow.edu.au.

${ }^{4}$ Redoviti profesor, Sungkyunkwan University, College of Economics, 25-2, Sungkyunkwan-ro, Jongno-gu, Seoul 03063, Republika Koreja. Znanstveni interes: cijena imovine, financijska ekonomija, tržišna mikrostruktura. Tel.: +822760 0429. Fax: +822760 0950.E-mail: sharpjin@ skku.edu. Personal website: https://sites.google.com/site/doojinryu/home/info (corresponding author). 